\title{
Article \\ Optimal Fall Protection System Selection Using a Fuzzy Multi-Criteria Decision-Making Approach for Construction Sites
}

\author{
Haifeng Jin ${ }^{1, *}$ and Paul M. Goodrum ${ }^{2}$ \\ 1 School of Economics and Management, University of Science and Technology Beijing, Beijing 100083, China \\ 2 Department of Construction Management, Colorado State University, Fort Collins, CO 80623-1584, USA; \\ paul.goodrum@colostate.edu \\ * Correspondence: haifengjin@ustb.edu.cn
}

Citation: Jin, H.; Goodrum, P.M. Optimal Fall Protection System Selection Using a Fuzzy Multi-Criteria Decision-Making Approach for Construction Sites. Appl. Sci. 2021, 11, 5296. https:// doi.org/10.3390/app11115296

Academic Editor: Jorge de Brito

Received: 6 May 2021

Accepted: 1 June 2021

Published: 7 June 2021

Publisher's Note: MDPI stays neutral with regard to jurisdictional claims in published maps and institutional affiliations.

Copyright: (C) 2021 by the authors. Licensee MDPI, Basel, Switzerland. This article is an open access article distributed under the terms and conditions of the Creative Commons Attribution (CC BY) license (https:// creativecommons.org/licenses/by/ $4.0 /)$.

\begin{abstract}
Construction falls are a leading cause of fatalities in almost every construction industry around the globe, and fall protection systems are the key measures to ensure the safety of labor crews. This study develops a fuzzy multi-criteria decision-making model integrating analytical hierarchy process, fuzzy set theory and Technique for Order Preference by Similarity to Ideal Solution approach to analyze the overall performance of various fall protection plans for construction projects, which focuses on evaluation and selection of the appropriate protection plan considering the most influential safety, productivity, and economy factors. Results show that the optimal plan can be effectively identified and determined among all potential alternatives. Besides, the model overcomes the shortcoming of weight value uncertainty and ambiguous decision information through membership function calculations. As a result, it provides guidance for the improvement of construction performance, intending to minimize fall risks, improve labor productivity, and save economical cost on the jobsites.
\end{abstract}

Keywords: construction industry (CI); fall protection system; safety performance; construction productivity; multi-criteria decision-making (MCDM)

\section{Introduction}

According to the U.S. Labor Statistics, the number of fatalities in the construction industry is higher than in all other industries, which accounts for nearly $20 \%$ of all workplace fatalities in 2015 [1,2]. However, the high trend of fatal and nonfatal rates in the construction industry continues in recent years [3,4]. One of the main risks related to construction safety are fall accidents and injuries on construction jobsites [5-7].

On actual construction jobsites, labor crews often need to work at above grade locations in order to complete certain tasks, such as bolting or welding tasks and working on roofs or scaffolds. While workers execute activities with bending, squatting, and kneeling postures, the postural stability will be reduced significantly, indicating that workers are likely to be exposed to falling hazards and are particularly at high risk of injury and fatality [8-13]. In the U.S. construction industry, fall accidents, such as falls to lower levels and same level, accounted for more than $40 \%$ of all fatal injuries [14]. Meanwhile, fall accidents are also the leading cause of construction accidents in many countries worldwide [15], such as UK [16], China [17,18], South Korea [19] and Singapore [20]. Due to fall injuries, construction workers are at significant risk of being affected by pain and inconvenience, and their families and the societies will be influenced by the medical and emotional burden [21]. In addition to compensation claims, work absenteeism and productivity losses due to fall accidents have been found to further indirectly compound the losses due to falls [22].

In order to reduce fall risk and prevent accidents before they occur, providing adequate and appropriate protection for workers has become the most effective preventative method 
on work jobsites. OSHA regulations stipulate that all workers must have fall protection while working above six feet or higher on a jobsite. As a result, various protection measures have been applied to prevent fall accidents, including both active and passive measures [23]. Specifically, active protection measures, such as guardrails, can prevent construction workers from falling, while passive measures, such as safety nets, protect workers after falling which effectively reduces the injury severity. In addition, many other protective methods have been used widely, for example, personal fall arrest systems (PFAS) and travel restraint systems [24,25]. However, no single method of fall protection can prevent all falls. A comprehensive fall protection plan that effectively meets the needs for safety requirements under various hazard conditions is required in the pre-construction phase [26,27].

This paper focuses on the optimal fall protection plan selection using an integrated multi-criteria decision-making approach, which interactively improves the safety performance, labor productivity and multiple managerial goals for construction projects. Compared to the current safety-related studies, this research combines the fuzzy AHP and TOPSIS method to optimize construction safety planning management according to the features of different hazard areas on jobsites. Specifically, the proposed model used the fuzzy AHP method to effectively determine the weights of all identified criteria during construction safety management, generated the ranking results of multiple potential safety plans based on the TOPSIS-based analysis, and therefore selected the optimal fall protection plan for construction jobsites. Furthermore, based on the obtained results from the fuzzy multi-criteria evaluation, a sensitivity analysis was conducted through a simulation-based approach to examine the stability of the ranking results to changes of the criteria weight values. As a result, the proposed method can be utilized to assist superintendents and work crews with an effective decision-making tool to select the optimal fall protection plan for complex projects considering multiple construction goals, including safety, labor productivity and economic benefits.

\section{Literature Review}

\subsection{Fall Protection in the Construction Industry}

Fall protection is a critical part of protecting work crews from fall injuries in construction. In order to reduce the risk of falling from height and ensure that labor crews work in a safe condition, OSHA regulations (C.F.R. 1926 Subpart M) require that worker crews must be protected when they are on a surface with an unprotected/hazard side or an edge of higher than 6 feet $(1.8 \mathrm{~m})$. Therefore, before the construction starts, the employer and superintendents are expected to develop an overall fall protection plan for the project. A comprehensive fall protection program should include policy statements, duties and responsibilities, training, fall hazard survey report, fall protection and emergency rescue procedures, fall hazards elimination or control, incidents investigation, and evaluation and review of fall protection programs [28]. However, current research mainly focuses on the identification of fall hazards and risk assessment. Various fall protection measures have not been comprehensively analyzed and selected according to the features of different hazardous work areas. As an effective fall protection plan, it should not be one form of fall protection measure, but a combination of several types of fall protection measures for different working conditions and activities [29]. Therefore, an effective and efficient safety planning decision-making tool is required to assist superintendents and work crews to select the optimal protection equipment for different hazards. Meanwhile, productivity and cost issues should also be taken into consideration to achieve better performance on jobsites.

Industry practitioners and researchers have adopted various safety evaluation approaches to assess fall risk in the pre-construction phase. The approaches mainly include the fall risk factors identification [30], quantification of safety risks [31-33], safety planning and control model generation [34,35], and virtual technology-based construction safety plan generation systems [4,36-38]. This safety planning and evaluation process is an essential part of safety management in construction. Previous research introduced multiple methods 
to identify the related safety factors, analyze and assess the prevention plans, and further improve the construction fall prevention performance. Cameron et al. [16] summarized the features of modern fall protection equipment and provided a comprehensive discussion on protection equipment selection, such as safety nets, fall arrest mats, and cable and track systems, which gives valuable advice and information to construction practitioners. To automate the fall prevention procedures, Navon and Kolton [39] developed a model to monitor fall hazards, which identifies and manages the fall hazards according to the involved activities and their schedule. Esmaeil et al. [40] proposed a framework to measure the effectiveness of common fall prevention/protection measures in residential building construction. Jebelli et al. [13] proposed a comprehensive method to analyze the fall risk of construction workers in stationary postures based on two stability metrics. To formalize the knowledge of active fall protection system design, Guo and Goh [41] developed an ontology which consists of nine core concepts: hazard, actor, task, IFC(Industry Foundation Classes) building elements, construction method, constraint, safety resource, hazard control measure, and residual risk. Zhang et al. [27] developed a safety rule-checking system integrated with a BIM platform, which automatically detects and prevents the fall-related hazards.

Although lots of construction fall prevention efforts have been made, fall accidents still occur on jobsites. Inadequate and inappropriate planning methods have been applied during the construction planning process [15,42]. As a comprehensive fall protection plan should combine multiple fall protection measures, the safety measures should be determined according to the task and hazard features on jobsites. Furthermore, the protection measures mainly include two categories: passive fall protection system and active fall protection system. Specifically, the passive protection system, such as safety nets, can protect workers after falling, which effectively reduces the injury severity [11], and the active protection system, such as personal fall arrest system [43], travel restraint system [41], guardrails [39], hole covering, and warning-line systems [44], can provide adequate fall protection for workers during the activity execution process. The above-mentioned measures are able to provide protection to work crews, however, current approaches are not able to assist superintendents and work crews to decide the most effective measures according to the task features to protect themselves while ensuring labor productivity. For example, in steel erection tasks, considering guardrails may be difficult to install on steel beams, the steel workers at high elevations need to use fall arrest systems during execution. Therefore, in order to protect work crews from potential fall hazards, a safety analyzing decision-making tool is needed to select the most appropriate protection equipment for different tasks at height on the jobsite.

\subsection{Multi-Criteria Decision-Making Models (MCDM) in Construction Industry}

In the construction industry, much knowledge and the provided information are imprecise, complex or incomplete [45]. Thus, construction safety planning problems are always associated with a set of factors, such as effectiveness, feasibility and cost, which are either quantitative or qualitative, and may be in conflict with each other. Construction safety planners need to deal with information vagueness and uncertainty, and finally make the optimal decision using the ambiguous data.

The Multi-criteria decision-making (MCDM) method is an effective approach in screening, prioritizing, ranking or selecting a set of alternatives with conflicting, incommensurate or independent attributes [46]. Different operational researchers and decision-making theorists have proposed many MCDM approaches and techniques, including simple additive weighting, analytical hierarchy process (AHP), Technique for Order Preference by Similarity to Ideal Solution (TOPSIS), VlseKriterijumska Optimizcija I Kaompromisno Resenje in Serbian (VIKOR), and Elimination Et Choix Traduisant la Realité (ELECTRE). However, the selection and applicability of a certain MCDM method largely depends on the available and collectable information that can be provided to the decision maker and the generated structure of the decision model. 
AHP is a method to determine the priority weights for multiple criteria in the decisionmaking system based on a rational framework of quantitative comparisons [47]. This approach has been widely applied in the risk assessment and management problems in the construction industry. During the AHP decision-making process, the knowledge about goals and priorities is not necessarily required [48]. The key step is to make pairwise comparison judgements through determination of the relative importance among different criteria.

TOPSIS was developed to determine the best solution for MCDM problems, which is proposed by Hwang and Yoon [46]. In the TOPSIS method, the positive and negative ideal solutions as the ideal and anti-ideal solutions, are determined, and the selected alternative should have the shortest distance from the positive ideal solution (PIS) and the farthest from the negative-ideal solution (NIS) [49]. Given that the results from TOPSIS are stable and the calculation process is easy to apply, TOPSIS has the fewest ranking reversals compared with other MCDM methods [46]. In previous construction safety related studies, many MCDM methods have been applied in areas of safety risk assessment [50-52], safety factor weighting [53], and priority evaluation [54]. Liaudanskiene et al. [55] used TOPSIS to determine the priorities of safety solutions, which effectively secures the employees' health and safety performance on construction sites. Bo [56] proposed a multi-criteria construction safety evaluation system based on a fuzzy TOPSIS method and further provides construction contractors and safety managers with guidelines to improve safety performance. The TOPSIS method is an effective and flexible method which can be easily understood and widely employed during safety planning in construction. Therefore, in this research, the TOPSIS method is extended and applied in the fall protection plan decision-making problem, and used in the evaluation and selection of the optimal fall protection solution for the construction project.

In the proposed MCDM system, AHP and TOPSIS are integrated with fuzzy sets to evaluate and determine the best fall protection system among construction safety plan alternatives. With the application of AHP and fuzzy TOPSIS, the fuzzy sets can be used to quantitatively describe subjective preference by simultaneously using the membership and non-membership functions, and the criteria weights, the positive-ideal solution and the negative-ideal solution can be further obtained. Integrating AHP, TOPSIS and fuzzy sets can fully take advantage of each. When decision-makers and planners face vague perceptions and incomplete information in construction management, AHP and fuzzy TOPSIS can improve the effectiveness and validity of MCDM problems.

\section{Methodology}

To investigate the construction safety effect of fall protection plans on overall performance onsite, this work follows the research workflow chart in Figure 1.

In Step 1, the AHP method is used to determine the criteria weight of the identified criteria in a construction fall protection plan decision-making problem. First, the potential fall protection alternatives for safety hazards were determined according to the safety requirements, industry regulations and experiences of managers/superintendents in construction [57]. The basic safety requirements to protect work crews were considered as the baseline to select fall protection measures/systems in the protection plan alternatives. Next, the multi-criteria decision-making model for construction fall protection system selection was established for the further assessment on the overall performance with all safety strategies. The related decision-making factors and criteria were identified through literature review and construction management experiences. Then, pairwise comparisons were conducted and the investigation data were obtained through in-depth surveys to construction mangers, superintendents and academic researchers. In Step 2, the fuzzy sets and TOPSIS principles were applied to evaluate and assess the overall performance of multiple fall protection plan alternatives. In this step, with all the alternatives and survey data at hand, the safety performance of the planning alternatives was analyzed through the proposed fuzzy TOPSIS assessment model procedure. In Step 3, a simulation-based 
sensitivity analysis is conducted to check the resulting stability and model response to the changes in the input data of parameters. Finally, the best fall protection alternative for work crews can be produced and determined.

\section{STEP 1}

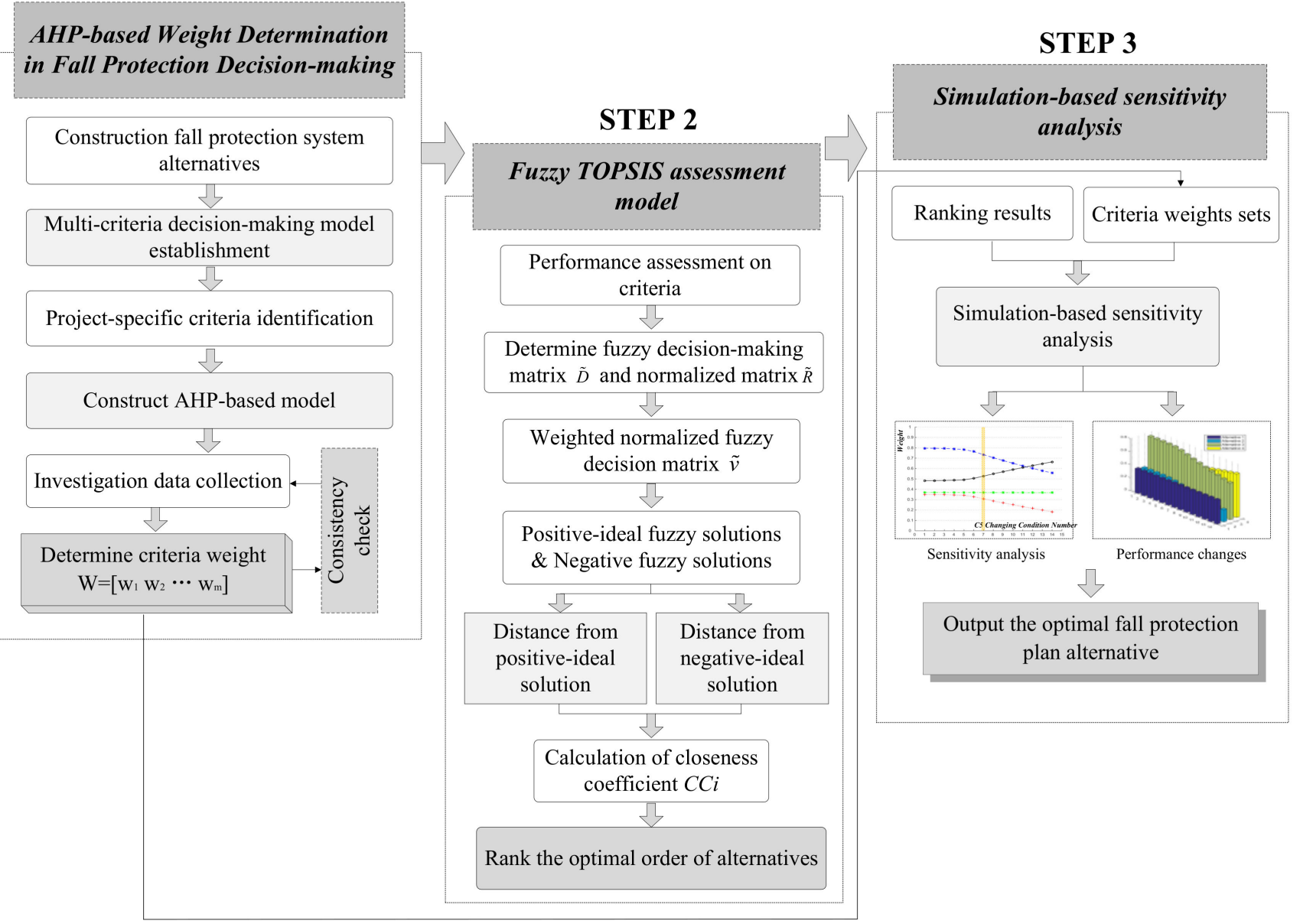

Figure 1. Research workflow of the safety performance assessment model procedure.

\subsection{Fall Protection Plan Decision-Making Model}

In the multi-criteria decision making for fall protection plan selection, the analyzing procedure includes three phases: (1) use analytic hierarchical process (AHP) to evaluate safety assessment criteria priorities; (2) integrate TOPSIS and fuzzy sets to rank the preference order of protection alternatives; (3) conduct simulation-based sensitivity analyses to test the resulting stability and robustness. The theories and methodology of step (1) and (2) are described in Sections 3.1.1 and 3.1.2, and step (3) will be addressed in details in Section 5 .

\subsubsection{Evaluate Construction Fall Protection System Alternatives Using AHP}

Using the AHP method, the multiple decision-making criteria can be broken down into two levels based on safety regulations and relevant literature, and analysis of expert opinions in the research area, as shown in Table 1. The first level comprises the main criteria, including: safety effectiveness, system implementation feasibility, construction productivity and cost. The second level consists of sub-criteria affecting the fall protection system selection. 
Table 1. Evaluation criteria for fall protection system selection.

\begin{tabular}{|c|c|c|}
\hline Criterion & Sub-Criterion & Definition \\
\hline \multirow{4}{*}{$\begin{array}{l}\text { Safety } \\
\text { effectiveness }\end{array}$} & $\begin{array}{l}\text { Equipment } \\
\text { appropriateness }\end{array}$ & $\begin{array}{l}\text { Selection of appropriate fall protection equipment according to } \\
\text { the task features and installation conditions on the } \\
\text { jobsite }[11,27,40,58-60] \text {. }\end{array}$ \\
\hline & End-user stability & $\begin{array}{l}\text { User stability on platform surface or construction components } \\
\text { using protection system }[11,61] \text {. }\end{array}$ \\
\hline & Protection to user & Protect workers from fall hazard area $[11,16,29,58,59,62]$. \\
\hline & Passivity & $\begin{array}{l}\text { The protection should be passive and does not need workers' } \\
\text { operation and participation after the system is installed }[16,29] \text {. }\end{array}$ \\
\hline \multirow{4}{*}{$\begin{array}{l}\text { Implementation } \\
\text { feasibility }\end{array}$} & Simplicity & $\begin{array}{l}\text { The protection plan should be easy to implement using } \\
\text { common resources and not difficult to understand }[16,29,58,62] \text {. }\end{array}$ \\
\hline & Aesthetics & $\begin{array}{l}\text { The appearance of the construction structure after the } \\
\text { protection system is installed }[16,58] \text {. }\end{array}$ \\
\hline & $\begin{array}{l}\text { Effort needed before } \\
\text { installation }\end{array}$ & $\begin{array}{l}\text { The need for extra effort to install the protection equipment if } \\
\text { working near fall hazard area [58]. }\end{array}$ \\
\hline & Flexibility & $\begin{array}{l}\text { The applicability of protection system that is being applied to } \\
\text { various task conditions and different phases of } \\
\text { construction }[29,63] \text {. }\end{array}$ \\
\hline \multirow{3}{*}{$\begin{array}{l}\text { Construction } \\
\text { productivity }\end{array}$} & $\begin{array}{l}\text { Labor productivity of } \\
\text { executing tasks }\end{array}$ & $\begin{array}{l}\text { Productivity of work crews and labor performance using the } \\
\text { protection system }[29,58,64] \text {. }\end{array}$ \\
\hline & $\begin{array}{l}\text { Ergonomic comfort of } \\
\text { workers }\end{array}$ & Ergonomic risk and posture comfort of worker crews $[29,65,66]$. \\
\hline & $\begin{array}{l}\text { Efficiency of } \\
\text { installation }\end{array}$ & $\begin{array}{l}\text { Working efficiency of labor crews during the protection } \\
\text { equipment installation }[16,29,62] \text {. }\end{array}$ \\
\hline \multirow{3}{*}{ Economy } & $\begin{array}{l}\text { Cost of protection } \\
\text { system }\end{array}$ & $\begin{array}{l}\text { The purchase or hire cost of protection system } \\
\text { package }[16,29,40] \text {. }\end{array}$ \\
\hline & Cost of system installation and removal & $\begin{array}{l}\text { The installation cost of protection equipment/system and } \\
\text { additional cost of equipment dismantling and removal [16]. }\end{array}$ \\
\hline & Maintenance and repair cost & Maintenance and repair cost of the equipment applied [11,16]. \\
\hline
\end{tabular}

\section{Safety Effectiveness}

Safety effectiveness is a key factor for fall protection and helps planners and construction managers to judge if the fall protection system can prevent worker crews from hazard areas and effectively protect crews from injuries. As the construction workforce is the most valuable resource in construction, the protection plan alternative should protect the workforce effectively during all phases in construction. For the safety effectiveness criterion, the sub-criteria of protection appropriateness, end-user stability, and protection to user and passivity were selected as the influential factors.

\section{Implementation Feasibility}

Implementation feasibility is a critical factor for fall protection system selection, because safety measures must be easy to implement to save time and cost. Before the task starts, a construction worker needs to put on the fall protection system (e.g., fall arrest system) in advance, therefore, the safety measures should be feasible and convenient to apply. Specifically, four sub-criteria were selected for the implementation feasibility, including the equipment installation simplicity, aesthetics of protection system, effort needed before installation and flexibility. 


\section{Construction Productivity}

The construction productivity criterion is a factor that is directly related to the construction workforce. As a worker may need to climb and execute tasks wearing the protection system, such as fall arrest system, the labor productivity may be affected. However, the application of some types of protection equipment will not only provide protection to workers but also improve the performance of workers. The protection equipment that is ergonomically designed is more comfortable and easier to use than other types of protection equipment that is not ergonomically designed. For example, if the fall arrest system used by the worker has a lightweight and functional harness, the worker will be able to attach more bags and tools to the belt, which effectively helps workers preserve travelling time and achieve higher productivity. Therefore, three sub-criteria were selected for the construction productivity criterion, including the sub-criteria of the labor productivity of executing tasks, ergonomic comfort of workers, and efficiency of installation.

\section{Economy}

The economy factor is related to the additional cost caused by using the protection equipment by work crews. The cost spent on the protection system varies with the selected types of fall protection systems. In order to choose the best safety plan, the additional cost spent on the protection systems needs to be calculated accurately, and the planners should compare the economic benefits among multiple safety plans. For economy consideration, factors of purchasing/rental cost of the protection system, system installation and removal cost, and the maintenance and repair cost were selected as three sub-criteria.

\subsubsection{Hierarchy of the Fall Protection System Decision-Making Problem Model Structure}

In this step, the criteria are identified and structured into three levels, each of which corresponds to a common feature of the elements in the same level, as shown in Figure 2. The 1st level focused on the decision problem. The 2nd level is the intermediate level corresponding to the decision criteria, while the 3rd level is the lowest level including the sub-criteria. Through the hierarchy structuring path, the complex decision problem is broken down into a set of major components, which is efficient and effective.

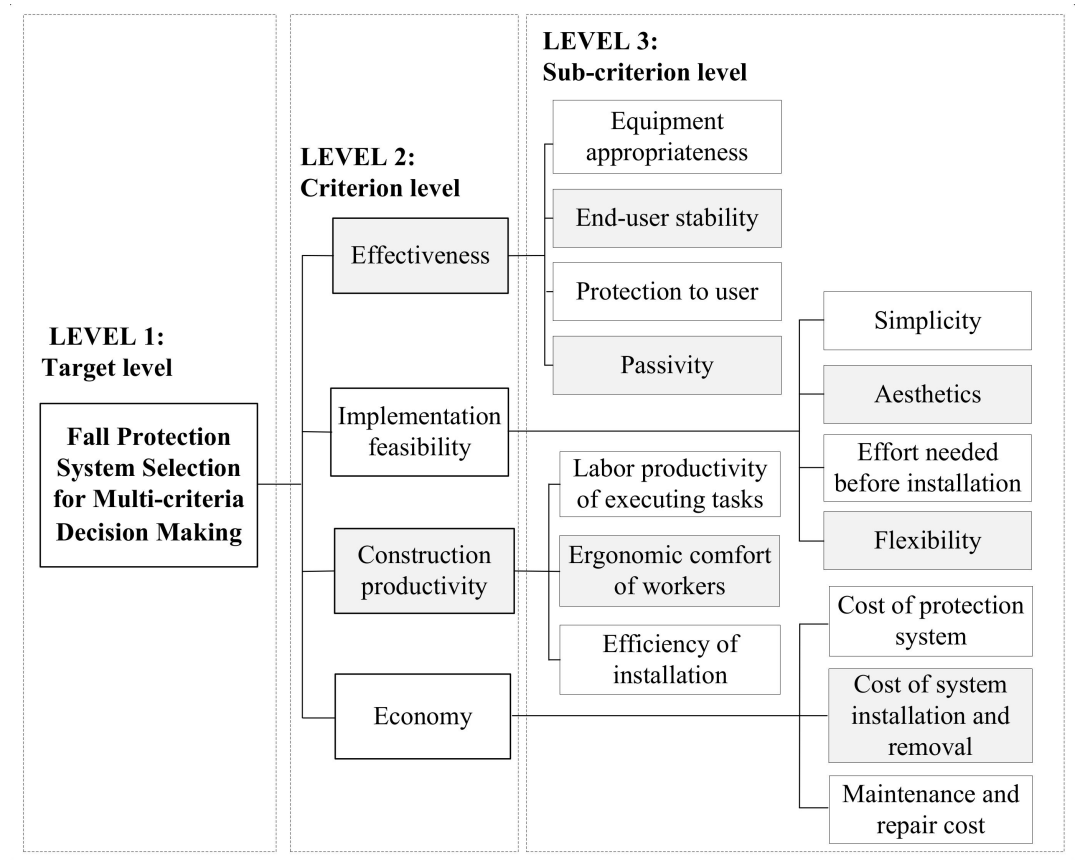

Figure 2. Hierarchy structure of evaluation criteria affecting the fall protection plan selection for a construction site. 


\subsubsection{Judgement of Relative Importance}

With respect to the decision-making objective, each two criteria on the same level were compared pairwisely. A nine-point scale was utilized to transform the respondent's judgements into numerical quantities as $a_{i j}$, which represent the relative importance of criterion $i$ with respect to criterion $j$ [67]. As illustrated in Table 2, the level of relative importance between two criteria was shown in numbers 1, 3, 5, 7 and 9. For example, 1 indicates equal importance of both criteria, while 9 indicates absolute importance of two criteria. Moreover, the intermediate values are represented as 2, 4, 6 and 8 .

Table 2. Pairwise comparison scale in AHP.

\begin{tabular}{cc}
\hline Relative Importance & Definition \\
\hline 1 & Criteria $\mathrm{i}$ and $\mathrm{j}$ are equally important. \\
3 & Criterion $\mathrm{i}$ is moderately more important than criterion $\mathrm{j}$. \\
5 & Criterion $\mathrm{i}$ is significantly more important than criterion $\mathrm{j}$. \\
7 & Criterion $\mathrm{i}$ is strongly more important than criterion $\mathrm{j}$. \\
9 & Criterion $\mathrm{i}$ is absolutely more important than criterion $\mathrm{j}$. \\
\hline
\end{tabular}

Through pairwise comparisons, an $n$-by- $n$ judgmental matrix $(A)$ is generated.

$$
A=\left[\begin{array}{cccc}
a_{11} & a_{12} & \cdots & a_{1 n} \\
a_{21} & a_{22} & \cdots & a_{2 n} \\
\cdots & \cdots & \cdots & \cdots \\
a_{n 1} & a_{n 1} & \cdots & a_{n n}
\end{array}\right]
$$

\subsubsection{Checking of Consistency}

The Consistency Index $(C I)$, which indicates the consistency of the pairwise comparison matrix $A$, is calculated and further checked. The Consistency ratio $(C R)$ value is obtained from the ratio of Consistency index $(C I)$ and Random index $(R I)$, where $R I$ is the consistency index of a randomly generated reciprocal matrix within a scale of 1-9.

$$
\begin{gathered}
C I=\frac{\lambda_{\max }-n}{n-1} \\
\lambda_{\text {max }}=\frac{1}{n} \sum_{i=1}^{n} \frac{(A w)_{i}}{w_{i}}
\end{gathered}
$$

where $\lambda_{\max }$ is the approximation of the maximum eigenvalue, and $n$ is the number of elements.

\subsubsection{Weighting Score Calculation}

The respondent's subjective judgment of relative importance among the criteria can be transformed into a quantitative analysis through the AHP methodology. Therefore, the weighting priorities can be further estimated by the calculation of the principal eigenvector of matrix $A$ as shown in Equation (4).

$$
A w=\lambda_{\max } \cdot w
$$

After the vector $w$ is normalized, the vector of the priorities is generated with respect to the decision-making goal.

\subsection{Fuzzy TOPSIS-Based Decision-Making Model for Construction Fall Protection Systems}

The fuzzy set theory was first introduced by Lotfi Zadeh to deal with approximate information rather than precise data [68]. In a fuzzy set, the belonging degree of each element to the set is defined as a membership function, where the membership function value can be taken as an intermediate value in the interval [0,1] [69]. In fuzzy set applica- 
tions, the degree of a criterion can be described as "excellence" or "like" by the decision makers or planners rather than precise assessments. Therefore, introducing fuzzy sets into decision-making problems is appropriate to rate the involved criteria.

Specifically, there are two definitions in fuzzy set applications that need to be clarified: (1) fuzzy set; and (2) fuzzy numbers. Let:

$$
\widetilde{A}=\left\{x, \mu_{A}(x)\right\}
$$

where $\widetilde{A}$ represents a fuzzy set in $X$, and $\mu_{A}(x): X \rightarrow[0,1]$ is the membership function which maps each $x$ in $X$ to a real number between 0 and 1 .

According to the membership function, the fuzzy set theory assesses the element $(x)$ in three scenarios: the membership grade of element $(x)$ equals to 0 , if the element is not in the fuzzy set $(\widetilde{A})$ (i.e., full non-membership); the membership grade equals to 1 , if the element is completely in the fuzzy set $(\widetilde{A})$ (i.e., full membership); and the membership grade is between 0 and 1 , if the element $(x)$ is partially in the fuzzy set $(\widetilde{A})$. In fuzzy set application problems, every linguistic assessment on criteria is matched with a fuzzy set. Therefore, decision makers define a membership function on each fuzzy set $X$ to obtain a membership degree in the interval $[0,1]$. Several different types of membership functions have been developed [70], and the most commonly applied one is the evenly-spaced triangular function, which simplifies the computation of transforming the input parameter variables into fuzzy variables.

The proposed model applies the fuzzy set logic and the TOPSIS approach in the performance assessment of fall protection systems. On the one hand, the fuzzy set logic is used to evaluate and analyze the fall protection system alternatives. On the other hand, the TOPSIS approach is applied to generate the optimal fall protection planning solution and help decision makers with selecting the best fall protection plan for the construction jobsite.

\subsubsection{Calculation of the Normalized Decision Matrix}

In the fuzzy TOPSIS method, in order to effectively evaluate the safety performance of fall protection alternatives, the fuzzy decision matrix is firstly established. The fuzzy decision matrix with $m$ rows and $n$ columns of the fuzzy MCDM problem can be expressed as Equation (6), where $m$ is the number of safety planning alternatives and $n$ is the number of criteria.

$$
\widetilde{D}=\begin{gathered}
C_{1} \\
A_{1} \\
A_{1} \\
\vdots \\
A_{1}
\end{gathered} \quad\left[\begin{array}{cccc}
\widetilde{x}_{11} & \widetilde{x}_{12} & \cdots & C_{n} \\
\widetilde{x}_{21} & \widetilde{x}_{22} & \cdots & \widetilde{x}_{1 n} \\
\vdots & \vdots & \ddots & \vdots \\
\widetilde{x}_{m 1} & \widetilde{x}_{m 2} & \cdots & \widetilde{x}_{n n}
\end{array}\right]
$$

where $\widetilde{D}$ represents the fuzzy decision matrix with alternatives $\left(A_{1}, A_{2}, \ldots, A_{m}\right)$ and criteria $\left(C_{1}, C_{2}, \ldots, C_{n}\right)$, and $\widetilde{x}_{i j}$ is the fuzzy number representing the performance of alternative $i$ with respect to criterion $j$.

Then, assuming that $\widetilde{P}=\left(p_{1}, p_{2}, p_{3}\right)$ and $\widetilde{Q}=\left(q_{1}, q_{2}, q_{3}\right)$ are two fuzzy numbers, the mathematical relations can be expressed as Equations (7) and (8) based on the calculation rules of the fuzzy set theory:

$$
\begin{gathered}
\widetilde{P} \oplus \widetilde{Q}=\left(p_{1}, p_{2}, p_{3}\right) \oplus\left(q_{1}, q_{2}, q_{3}\right)=\left(p_{1}+q_{1}, p_{2}+q_{2}, p_{3}+q_{3}\right) \\
\widetilde{P} \bigotimes \widetilde{Q}=\left(p_{1}, p_{2}, p_{3}\right) \bigotimes\left(q_{1}, q_{2}, q_{3}\right)=\left(p_{1} q_{1}, p_{2} q_{2}, p_{3} q_{3}\right)
\end{gathered}
$$

After the initial fuzzy decision matrix is generated, it can be normalized to matrix $\widetilde{R}$ as Equation (9):

$$
\widetilde{R}=\left[r_{i j}\right]_{m \times n^{\prime}} i=1,2, \ldots, ; j=1,2, \ldots, n
$$


In this study, the criteria can be summarized into two category types: the "benefit criteria" and the "cost criteria". To this end, the criteria can be normalized through Equation (10) or Equation (11) based on the corresponding criterion type.

$$
\widetilde{r}_{i j}=\left(\frac{a_{i j}}{c_{j}^{*}}, \frac{b_{i j}}{c_{j}^{*}}, \frac{c_{i j}}{c_{j}^{*}}\right), j \in B
$$

where $c_{j}^{*}=\max _{i} c_{i j}, j \in B$, and $B$ represents the set of benefit criteria.

$$
\widetilde{r}_{i j}=\left(\frac{a_{j}^{-}}{c_{i j}}, \frac{a_{j}^{-}}{b_{i j}}, \frac{a_{j}^{-}}{a_{i j}}\right), j \in C
$$

where $a_{j}^{-}=\min _{i} a_{i j}, j \in C$, and $C$ represents the set of cost criteria.

\subsubsection{Generation of Weighted Normalized Fuzzy Decision Matrix}

Let $w_{j}$ representing the weight for criterion $j$, the weighted normalized fuzzy decision matrix is calculated through Equation (12).

$$
\widetilde{v}=\left[\widetilde{v}_{i j}\right]_{m \times n^{\prime}}, i=1,2, \ldots, m ; j=1,2, \ldots, n . \widetilde{v}_{i j}=\widetilde{r}_{i j} \bigotimes \widetilde{w}_{i j}
$$

where $w_{j}$ represents the weight for criterion $j$, whose value can be obtained from the previously addressed AHP method.

\subsubsection{TOPSIS-Based Evaluation}

The weighted matrix $\widetilde{v}$ is used as the input data for the TOPSIS-based evaluation model. The model evaluates multiple alternatives based on the distance from the positive and negative ideal points to each alternative. The positive ideal solution $\left(A_{j}^{+}\right)$and negative ideal solution $\left(A_{j}^{-}\right)$are determined according to the weighted normalized values:

$$
\begin{aligned}
& A_{j}^{+}=\left\{\widetilde{v}_{1}^{+}, \widetilde{v}_{2}^{+}, \ldots, \widetilde{v}_{n}^{+}\right\}=\left\{\left(\max _{i} v_{i j} \mid j \in B\right),\left(\min _{i} v_{i j} \mid j \in C\right) \mid i=1,2, \ldots, m\right\} \\
& A_{j}^{-}=\left\{\widetilde{v}_{1}^{-}, \widetilde{v}_{2}^{-}, \ldots, \widetilde{v}_{n}^{-}\right\}=\left\{\left(\min _{i} v_{i j} \mid j \in B\right),\left(\max _{i} v_{i j} \mid j \in C\right) \mid i=1,2, \ldots, m\right\}
\end{aligned}
$$

The distance from the positive-ideal reference point $\left(A_{j}^{+}\right)$and the negative-ideal reference point $\left(A_{j}^{-}\right)$are measured by the Euclidean distances in Equations (13) and (14), respectively.

$$
\begin{aligned}
& d_{i}^{+}=\sqrt{\left(\sum_{j=1}^{n}\left(\widetilde{v}_{i j}-\widetilde{v}_{j}^{+}\right)^{2}\right)}, i=1,2, \ldots, m ; j=1,2, \ldots, n \\
& d_{i}^{-}=\sqrt{\left(\sum_{j=1}^{n}\left(\widetilde{v}_{i j}-\widetilde{v}_{j}^{-}\right)^{2}\right)}, i=1,2, \ldots, m ; j=1,2, \ldots, n
\end{aligned}
$$

where $d_{j}^{+}$in Equation (13) represents the distance from the positive-ideal reference point and $d_{i}^{-}$in Equation (14) represents the distance from the negative-ideal reference point.

According to the obtained values of distances $d_{j}^{+}$and $d_{i}^{-}$, the closeness coefficient $\left(C C_{i}\right)$ for fall protection alternative $i$ can be calculated through Equation (15).

$$
C C_{i}=\frac{d_{i}^{-}}{d_{j}^{+}+d_{i}^{-}}, i=1,2, \ldots, m
$$


Finally, the ranking of all alternatives can be determined according to the value of $C_{i}$. The performance ranking of all alternatives is achieved by the values of close coefficient $C C_{i}$, where a higher $C C_{i}$ indicates a better alternative. Therefore, the fall protection plan with a higher $C C_{i}$ is at the top of the priority ranking list. The fall protection alternative ranking results can be generated through the combined fuzzy set theory and TOPSIS technique, which effectively assists the decision-makers and planners in selecting the optimal alternative in construction safety management.

\section{Case Study}

To demonstrate the implementation of the proposed AHP and fuzzy TOPSIS integrated multi-criteria decision-making model, a case study of a construction project was conducted. The application project includes two main work areas as shown in the 3D BIM model in Figure 3: one work area of a multi-storey office building and a single-storey industrial plant.

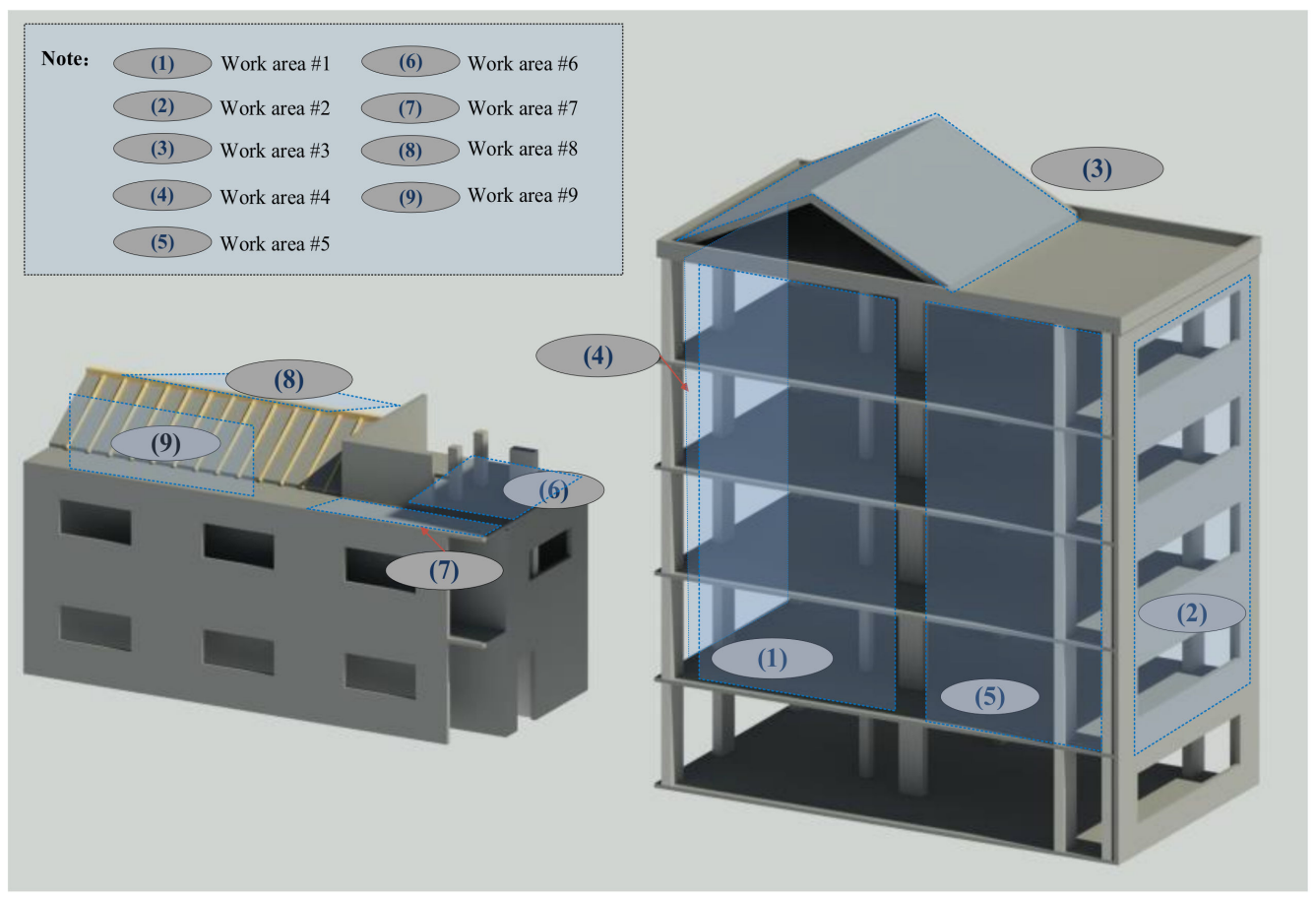

Figure 3. 3D BIM model of the construction project and hazard area divisions.

As shown in Figure 3, the construction structure of the main body was completed, however, the exterior walls and roof tasks needed to be constructed. To execute the masonry tasks and other activities on the floors and roofs, labor crews need to be exposed to the hazardous edges. To conduct effective safety planning for the jobsite, the jobsite area was divided into nine independent work areas. For example, in work area 1, 4, 5, 6, 7 and 9, the concrete tasks on each floor and the masonry activities to be executed were within the fall hazard zones. In work area 2, there were activities related to window installations. In this case, there is a high risk of falling and injuries to the work crews. For safety and security reasons, window installation and maintenance workers should use fall protection systems when working at height. In work area 3 and 8, while there were openings and hazard zones on roofs, work crews must perform tasks using proper equipment to ensure their safety and prevent falls and injuries effectively. 
Therefore, for this construction project, four safety plan alternatives were derived in the planning phase by optimizing the safety, productivity and cost objectives. In the potential safety alternatives, five fall protection systems were adopted as illustrated in Table 3, which are, respectively: guardrail system, warning line system, personal fall arrest system (PFAS), travel restraint system and hole covering measure. Based on the protection requirements in each planning work area and the features of each fall protection measure, the corresponding protection systems in each potential alternative for the work areas are shown in Table 4. In this case study, four safety plan alternatives were evaluated through the fuzzy multi-criteria framework considering fourteen decision criteria, indicating that the values of $m$ and $n$ in Section 3 are, respectively, 4 and 14 .

Table 3. Illustration of feasible fall protection systems.

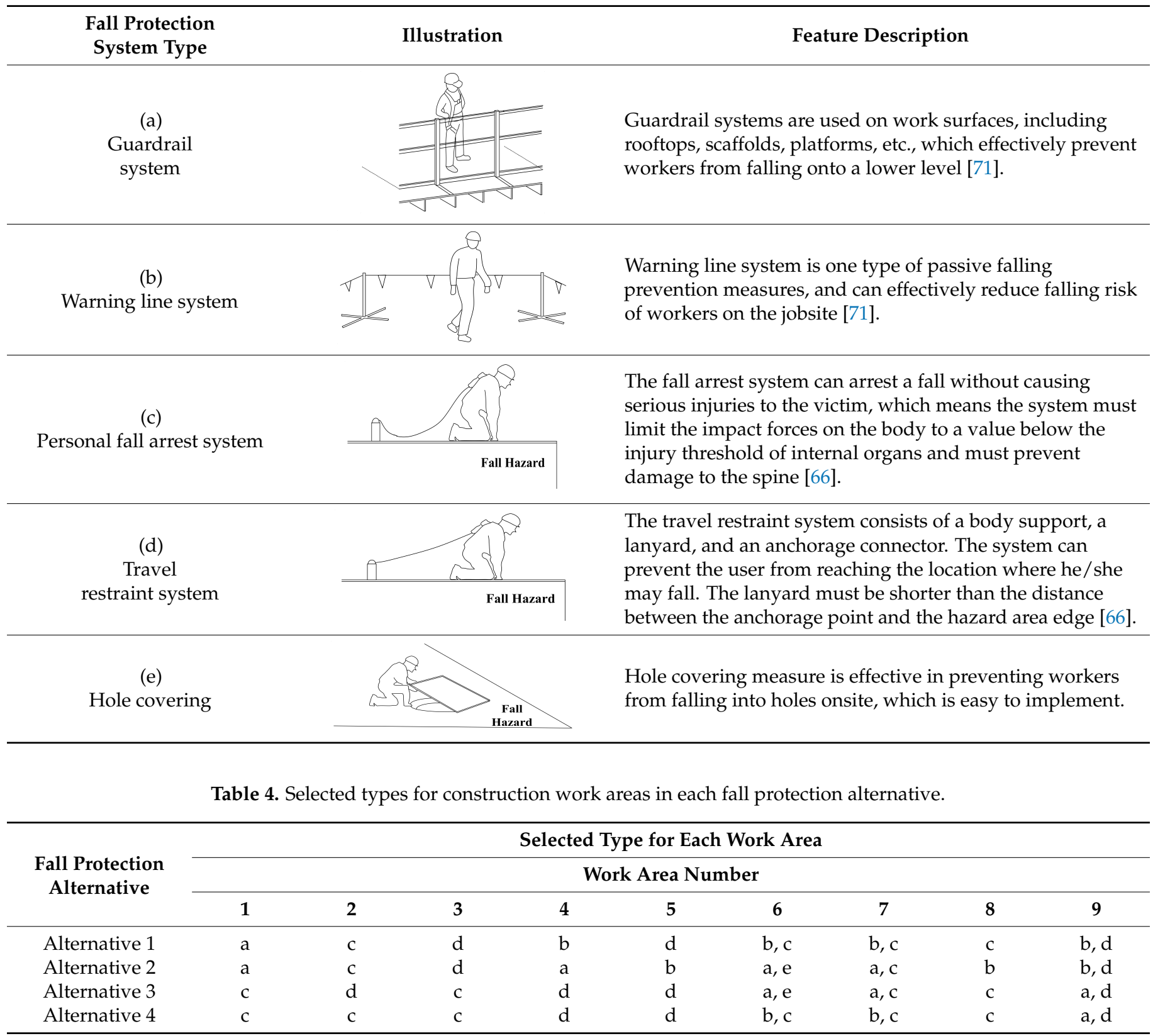




\subsection{Determination of the Criteria Weights Using AHP in the Fall Protection System Decision-Making Model}

In this research, planners and construction managers are required to obtain the criteria weights for further decision making to assess each fall protection alternative in terms of predefined criteria, as illustrated in Figure 2. Considering the criteria in the decision-making hierarchy are related to safety, implementation feasibility, productivity and economy aspect, multiple experts with the corresponding working background were selected to provide decision information. For this case study, eight experts were selected in the investigation to assess the relative importance of the identified criteria and alternative performance, and they have different working background of construction planning, Occupational Health and Safety (OHS) management, safety management, construction management, supervision, task execution work, operational management and cost management, as shown in Table 5. As the background of the selected experts includes safety, productivity, and cost management jobs on sites, and the experts also have rich experiences with average working years of 11.1 in the construction field, the obtained information from eight experts can be adequate and effective for further analysis.

Table 5. Details about experts and working experience.

\begin{tabular}{ccc}
\hline Respondent No. & Title & Working Experience \\
\hline Expert 1 & Construction planner & 10 \\
Expert 2 & OHS expert & 15 \\
Expert 3 & Construction safety expert & 18 \\
Expert 4 & Construction manager & 10 \\
Expert 5 & Construction supervisor & 11 \\
Expert 6 & Construction worker & 8 \\
Expert 7 & Operation manager & 10 \\
Expert 8 & Cost manager & 9 \\
\hline
\end{tabular}

In the investigation, each case study participant evaluated the relative importance between different criteria using the 1-9 scale method shown in Table 2, respectively. The semantic descriptions were transformed into accurate scores according to the presented rules in Table 2. As indicated in Figure 4, the pairwise comparison matrices obtained from initial investigation results were used in the fall protection plan evaluation and selection phase.

The normalized weights for each main criterion and sub-criterion in the hierarchy structure are shown in Figure 5. The corresponding values of the weights were calculated according to the safety and economic contribution for workers in the unsafe working condition during construction. The normalized weights reflect the relative importance of all criteria based on the average results from the respondents involved in the questionnaire investigation. Among the four main criteria, the weight of safety effectiveness criterion is the highest, with a weight value of 0.505 , while the economy criterion weight is the lowest, with a value of 0.0932. As indicated in Figure 5, the sub-criteria of "Protection to user" and "Equipment selection" were of top priorities that resulted in weighting values of 0.222 and 0.152 , respectively. The weights shown in Figure 5 were further used in the alternative evaluation and selection for fall protection planning. 


\begin{tabular}{|c|c|c|c|c|}
\hline & Effectiveness & $\begin{array}{l}\text { Implementati } \\
\text { feasibility }\end{array}$ & $\begin{array}{l}\text { on Construction } \\
\text { productivity }\end{array}$ & Economy \\
\hline Effectiveness & 1.00 & 3.00 & 3.00 & 4.00 \\
\hline $\begin{array}{l}\text { Implementation } \\
\text { feasibility }\end{array}$ & 0.33 & 1.00 & 2.00 & 3.00 \\
\hline $\begin{array}{l}\text { Construction } \\
\text { productivity }\end{array}$ & 0.33 & 0.50 & 1.00 & 2.00 \\
\hline Economy & 0.25 & 0.33 & 0.50 & 1.00 \\
\hline
\end{tabular}

\begin{tabular}{|c|c|c|c|c|}
\hline & $\begin{array}{c}\text { Equipment } \\
\text { appropriateness }\end{array}$ & $\begin{array}{l}\text { End-user } \\
\text { stability }\end{array}$ & $\begin{array}{l}\text { Protection } \\
\text { to user }\end{array}$ & Passivity \\
\hline $\begin{array}{l}\text { Equipment } \\
\text { appropriateness }\end{array}$ & 1.00 & 2.00 & 0.50 & 4.00 \\
\hline $\begin{array}{l}\text { End-user } \\
\text { stability }\end{array}$ & 0.50 & 1.00 & 0.33 & 2.00 \\
\hline $\begin{array}{l}\text { Protection } \\
\text { to user }\end{array}$ & 2.00 & 3.00 & 1.00 & 3.00 \\
\hline Passivity & 0.25 & 0.50 & 0.33 & 1.00 \\
\hline
\end{tabular}

\begin{tabular}{|c|c|c|c|c|}
\hline & Simplicity & Aesthetics & $\begin{array}{l}\text { Efforts nee } \\
\text { before instal }\end{array}$ & Flexibility \\
\hline Simplicity & 1.00 & 3.00 & 0.50 & 0.50 \\
\hline Aesthetics & 0.33 & 1.00 & 0.50 & 0.33 \\
\hline $\begin{array}{c}\text { Efforts needed } \\
\text { before installation }\end{array}$ & 2.00 & 2.00 & 1.00 & 0.33 \\
\hline Flexibility & 2.00 & 2.00 & 3.00 & 1.00 \\
\hline
\end{tabular}

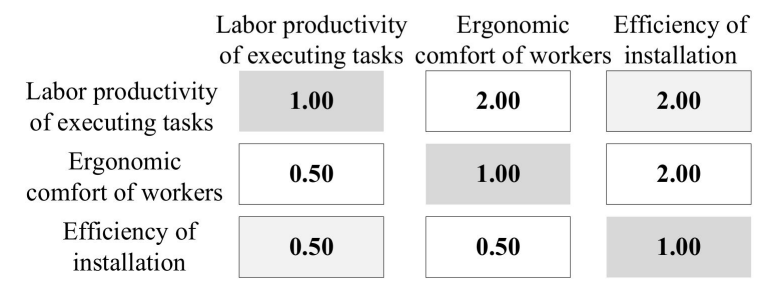

\begin{tabular}{|c|c|c|c|}
\hline & $\begin{array}{l}\text { Cost of protection } \\
\text { system }\end{array}$ & $\begin{array}{l}\text { Cost of system } \\
\text { installation and } \\
\text { removal }\end{array}$ & $\begin{array}{l}\text { Maintenance } \\
\text { and repair cost }\end{array}$ \\
\hline $\begin{array}{l}\text { Cost of protection } \\
\text { system }\end{array}$ & 1.00 & 2.00 & 2.00 \\
\hline $\begin{array}{l}\text { Cost of system } \\
\text { installation and }\end{array}$ & 0.50 & 1.00 & 2.00 \\
\hline $\begin{array}{l}\text { Maintenance } \\
\text { and repair cost }\end{array}$ & 0.50 & 0.50 & 1.00 \\
\hline
\end{tabular}

Figure 4. Pairwise comparisons between each two criteria in the fall protection plan selection decision-making problem.

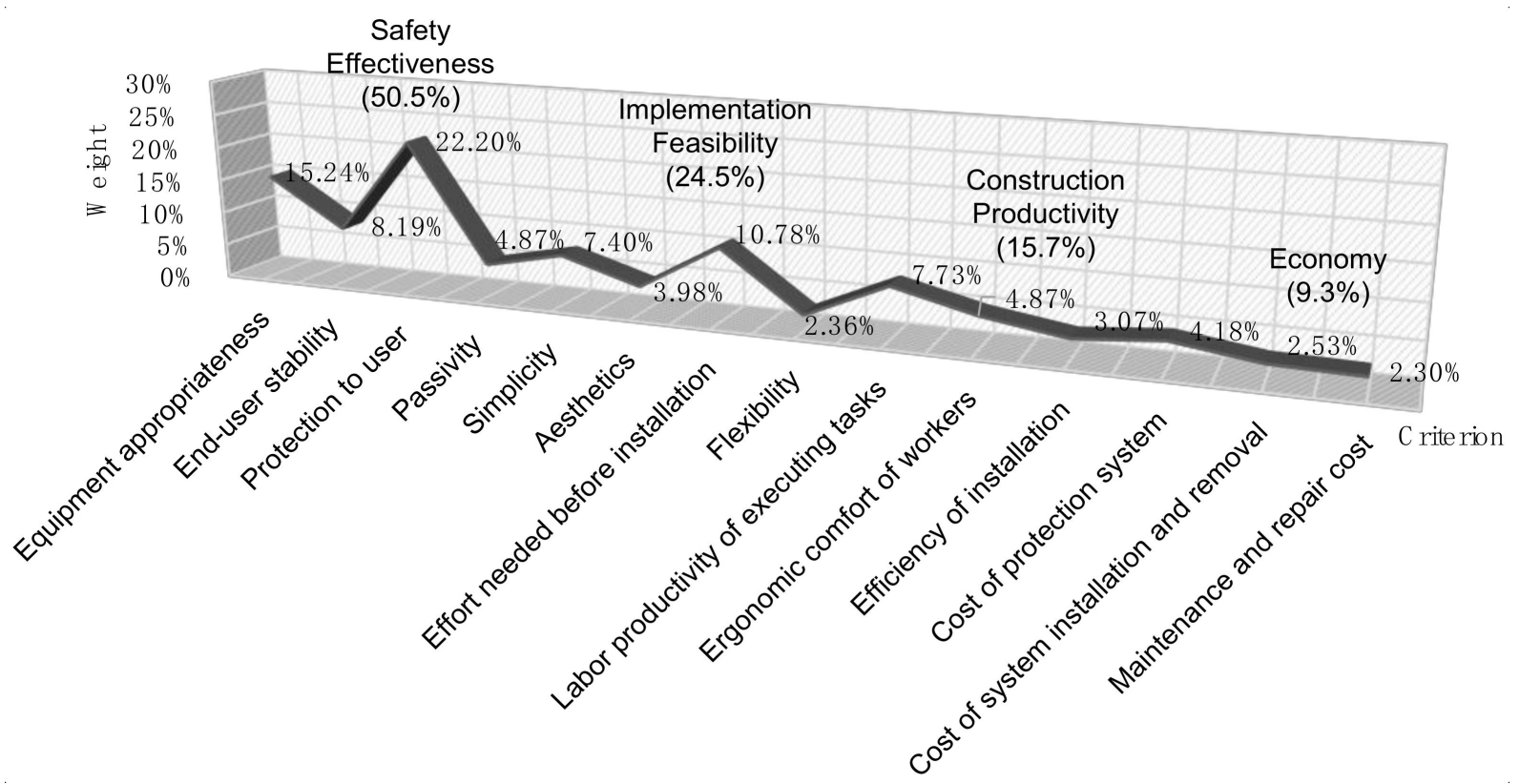

Figure 5. Normalized weight values of main criteria and sub-criteria in the fall protection alternative decision-making model. 


\subsection{Performance Evaluation Using Fuzzy MCDM Model in the Construction Project}

The proposed fuzzy TOPSIS model of fall protection system decision-making is employed to select the optimal fall protection plan. The involved experts shown in Table 4 reviewed the performance of all alternatives and assessed each criterion for each hazardous working area. The linguistic variables were obtained from the respondents, such as "very low", "fair", "medium high" and "very high". In order to transform the linguistic variables into quantitative expressions, the transformation rules for criteria performance need to be set. Therefore, the fuzziness of human thoughts is incorporated into the decision-making model through linguistic evaluations, which is illustrated in Table 6. Thus, the linguistic rating judgments on performance of criteria of each alternative are performed by the respondents. The results of initial fuzzy rating are averaged to generate the accurate performance values of all criteria in each alternative. The fuzzy evaluation data for Alternative 1 are illustrated in Table 7.

Table 6. Transformation rules of linguistic variables of decision makers to fuzzy numbers for criteria performance of planning alternatives.

\begin{tabular}{cc}
\hline Linguistic Terms & Corresponding Triangular Fuzzy Number \\
\hline Very low (VL) & $(0,0,1)$ \\
Low (L) & $(0,1,3)$ \\
Medium low (ML) & $(1,3,5)$ \\
Fair (F) & $(3,5,7)$ \\
Medium high (MH) & $(5,7,9)$ \\
High (H) & $(7,9,10)$ \\
Very high (VH) & $(9,10,10)$ \\
\hline
\end{tabular}

Table 7. Matrix of fuzzy evaluation data for Alternative 1.

\begin{tabular}{|c|c|c|c|c|c|c|c|c|}
\hline \multirow{2}{*}{ Criteria } & \multicolumn{8}{|c|}{ Triangular Fuzzy Numbers Obtained from Each Respondent $\left(\mathbf{R}_{\mathbf{i}}\right)$} \\
\hline & R1 & $\mathbf{R} 2$ & R3 & R4 & R5 & R6 & R7 & R8 \\
\hline Equipment appropriateness & $(1,3,5)$ & $(3,5,7)$ & $(1,3,5)$ & $(0,1,3)$ & $(1,3,5)$ & $(3,5,7)$ & $(1,3,5)$ & $(0,1,3)$ \\
\hline End-user stability & $(5,7,9)$ & $(7,9,10)$ & $(5,7,9)$ & $(3,5,7)$ & $(5,7,9)$ & $(7,9,10)$ & $(5,7,9)$ & $(3,5,7)$ \\
\hline Protection to user & $(5,7,9)$ & $(7,9,10)$ & $(5,7,9)$ & $(5,7,9)$ & $(5,7,9)$ & $(3,5,7)$ & $(3,5,7)$ & $(3,5,7)$ \\
\hline Passivity & $(1,3,5)$ & $(3,5,7)$ & $(1,3,5)$ & $(0,1,3)$ & $(1,3,5)$ & $(3,5,7)$ & $(1,3,5)$ & $(3,5,7)$ \\
\hline Simplicity & $(1,3,5)$ & $(3,5,7)$ & $(0,1,3)$ & $(1,3,5)$ & $(3,5,7)$ & $(1,3,5)$ & $(1,3,5)$ & $(3,5,7)$ \\
\hline Aesthetics & $(1,3,5)$ & $(0,1,3)$ & $(1,3,5)$ & $(1,3,5)$ & $(1,3,5)$ & $(0,1,3)$ & $(1,3,5)$ & $(3,5,7)$ \\
\hline Effort needed before installation & $(3,5,7)$ & $(5,7,9)$ & $(5,7,9)$ & $(7,9,10)$ & $(5,7,9)$ & $(7,9,10)$ & $(5,7,9)$ & $(3,5,7)$ \\
\hline Flexibility & $(1,3,5)$ & $(0,1,3)$ & $(1,3,5)$ & $(3,5,7)$ & $(1,3,5)$ & $(3,5,7)$ & $(1,3,5)$ & $(1,3,5)$ \\
\hline Labor productivity & $(3,5,7)$ & $(5,7,9)$ & $(7,9,10)$ & $(5,7,9)$ & $(5,7,9)$ & $(3,5,7)$ & $(3,5,7)$ & $(5,7,9)$ \\
\hline Ergonomic comfort of workers & $(3,5,7)$ & $(5,7,9)$ & $(5,7,9)$ & $(5,7,9)$ & $(7,9,10)$ & $(5,7,9)$ & $(3,5,7)$ & $(5,7,9)$ \\
\hline Efficiency of installation & $(0,1,3)$ & $(1,3,5)$ & $(1,3,5)$ & $(3,5,7)$ & $(1,3,5)$ & $(1,3,5)$ & $(0,1,3)$ & $(0,1,3)$ \\
\hline Cost of protection system & $(5,7,9)$ & $(7,9,10)$ & $(5,7,9)$ & $(3,5,7)$ & $(5,7,9)$ & $(5,7,9)$ & $(7,9,10)$ & $(5,7,9)$ \\
\hline Cost of installation and removal & $(5,7,9)$ & $(3,5,7)$ & $(5,7,9)$ & $(5,7,9)$ & $(5,7,9)$ & $(3,5,7)$ & $(5,7,9)$ & $(5,7,9)$ \\
\hline Maintenance and repair cost & $(5,7,9)$ & $(3,5,7)$ & $(5,7,9)$ & $(5,7,9)$ & $(7,9,10)$ & $(5,7,9)$ & $(5,7,9)$ & $(3,5,7)$ \\
\hline
\end{tabular}

As given in Table 8, based on the normalized weights and the fuzzy matrix obtained previously, the fuzzy-weighted normalized matrix is calculated using Equation (12).

Then, the fuzzy ideal positive solutions $\left(A_{j}^{+}\right)$and fuzzy ideal negative solutions $\left(A_{j}^{-}\right)$ for the sub-criteria for each fall protection plan alternative can be determined through Equations (13) and (14), as illustrated in Table 9. 
Table 8. Fuzzy-weighted normalized decision matrix for construction fall protection alternatives.

\begin{tabular}{ccccc}
\hline Decision Sub-Criteria & \multicolumn{3}{c}{ Fall Protection System Plan Alternatives } \\
\cline { 2 - 5 } & Alternative 1 & Alternative 2 & Alternative 3 & Alternative 4 \\
\hline Equipment appropriateness & $(0.00,0.05,0.11)$ & $(0.00,0.05,0.11)$ & $(0.05,0.10,0.15)$ & $(0.02,0.05,0.11)$ \\
End-user stability & $(0.02,0.06,0.08)$ & $(0.02,0.05,0.08)$ & $(0.02,0.05,0.08)$ & $(0.02,0.05,0.08)$ \\
Protection to user & $(0.07,0.14,0.22)$ & $(0.02,0.13,0.20)$ & $(0.07,0.17,0.22)$ & $(0.07,0.08,0.22)$ \\
Passivity & $(0.00,0.02,0.03)$ & $(0.01,0.03,0.05)$ & $(0.01,0.04,0.05)$ & $(0.01,0.04,0.05)$ \\
Simplicity & $(0.00,0.03,0.05)$ & $(0.00,0.02,0.04)$ & $(0.00,0.02,0.05)$ & $(0.02,0.05,0.07)$ \\
Aesthetics & $(0.00,0.01,0.03)$ & $(0.00,0.02,0.04)$ & $(0.00,0.02,0.03)$ & $(0.00,0.02,0.04)$ \\
Flexibility & $(0.03,0.05,0.11)$ & $(0.03,0.04,0.11)$ & $(0.03,0.04,0.11)$ & $(0.03,0.05,0.11)$ \\
Effort needed before installation & $(0.00,0.01,0.02)$ & $(0.00,0.01,0.02)$ & $(0.00,0.00,0.01)$ & $(0.00,0.01,0.02)$ \\
Labor productivity & $(0.02,0.05,0.08)$ & $(0.02,0.03,0.08)$ & $(0.02,0.03,0.08)$ & $(0.02,0.05,0.07)$ \\
Ergonomic comfort of workers & $(0.01,0.03,0.05)$ & $(0.01,0.04,0.05)$ & $(0.00,0.02,0.03)$ & $(0.01,0.03,0.05)$ \\
Efficiency of installation & $(0.00,0.01,0.02)$ & $(0.00,0.01,0.03)$ & $(0.02,0.03,0.03)$ & $(0.01,0.02,0.03)$ \\
Cost of protection system & $(0.00,0.01,0.01)$ & $(0.00,0.01,0.01)$ & $(0.01,0.01,0.04)$ & $(0.00,0.01,0.01)$ \\
Cost of installation and removal & $(0.00,0.00,0.01)$ & $(0.00,0.00,0.01)$ & $(0.00,0.01,0.03)$ & $(0.00,0.01,0.03)$ \\
Maintenance and repair cost & $(0.01,0.01,0.02)$ & $(0.01,0.01,0.02)$ & $(0.01,0.01,0.02)$ & $(0.01,0.01,0.02)$ \\
\hline
\end{tabular}

Table 9. Positive distance and negative distance of fall protection alternatives.

\begin{tabular}{|c|c|c|c|c|c|c|c|c|}
\hline \multirow{3}{*}{ Decision Sub-Criteria } & \multicolumn{8}{|c|}{ Positive Distance and Negative Distance of Fall Protection System Alternatives } \\
\hline & \multicolumn{2}{|c|}{ Alternative 1} & \multicolumn{2}{|c|}{ Alternative 2} & \multicolumn{2}{|c|}{ Alternative 3} & \multicolumn{2}{|c|}{ Alternative 4} \\
\hline & $\mathrm{d}^{+}$ & $\mathbf{d}^{-}$ & $\mathrm{d}^{+}$ & $\mathbf{d}^{-}$ & $\mathbf{d}^{+}$ & $\mathbf{d}^{-}$ & $\mathrm{d}^{+}$ & $\mathbf{d}^{-}$ \\
\hline Equipment appropriateness & 0.086 & 0.000 & 0.086 & 0.000 & 0.000 & 0.086 & 0.074 & 0.017 \\
\hline End-user stability & 0.000 & 0.006 & 0.004 & 0.002 & 0.004 & 0.002 & 0.006 & 0.000 \\
\hline Protection to user & 0.028 & 0.083 & 0.067 & 0.050 & 0.000 & 0.107 & 0.094 & 0.050 \\
\hline Passivity & 0.029 & 0.000 & 0.003 & 0.027 & 0.000 & 0.029 & 0.002 & 0.028 \\
\hline Simplicity & 0.038 & 0.017 & 0.052 & 0.000 & 0.043 & 0.015 & 0.000 & 0.052 \\
\hline Aesthetics & 0.013 & 0.000 & 0.000 & 0.013 & 0.010 & 0.006 & 0.001 & 0.013 \\
\hline Effort needed before installation & 0.000 & 0.004 & 0.003 & 0.001 & 0.004 & 0.000 & 0.000 & 0.004 \\
\hline Flexibility & 0.008 & 0.006 & 0.010 & 0.006 & 0.014 & 0.000 & 0.000 & 0.014 \\
\hline Labor productivity & 0.000 & 0.024 & 0.023 & 0.008 & 0.019 & 0.009 & 0.008 & 0.021 \\
\hline Ergonomic comfort of workers & 0.004 & 0.022 & 0.000 & 0.024 & 0.024 & 0.000 & 0.004 & 0.022 \\
\hline Efficiency of installation & 0.025 & 0.000 & 0.017 & 0.010 & 0.000 & 0.025 & 0.008 & 0.018 \\
\hline Cost of protection system & 0.029 & 0.000 & 0.029 & 0.000 & 0.000 & 0.029 & 0.029 & 0.001 \\
\hline Cost of installation and removal & 0.017 & 0.000 & 0.017 & 0.000 & 0.000 & 0.017 & 0.003 & 0.017 \\
\hline Maintenance and repair cost & 0.003 & 0.001 & 0.004 & 0.000 & 0.000 & 0.004 & 0.003 & 0.001 \\
\hline
\end{tabular}

Based on Equation (15), the closeness of each fall protection plan alternative to the ideal solution is calculated. As given in Table 10, the performances of all indices are computed to rank the fall protection alternatives. The obtained results show that the fall protection plan A3 achieves the best overall performance with the highest closeness coefficient of 0.734 in the case study. Therefore, Alternative 3 can be selected as the optimal fall protection plan for this construction project, which indicates that the personal fall arrest system (option c shown in Table 3) will be applied to work area 1, 3, 7 and 8, travel restraint system (option d) will be applied to work area 2, 4, 5 and 9, guardrail system (option a) will be applied to work area 6,7 and 9, and hole covering (option e) will be applied to work area 6. 
Table 10. Closeness coefficients among different fall protection plan alternatives.

\begin{tabular}{ccccc}
\hline Alternatives & $d_{j}^{+}$ & $d_{j}^{-}$ & $C C_{i}$ & Ranking \\
\hline A1 & 0.281 & 0.165 & 0.369 & 3 \\
A2 & 0.316 & 0.141 & 0.308 & 4 \\
A3 & 0.119 & 0.328 & 0.734 & 1 \\
A4 & 0.232 & 0.259 & 0.528 & 2 \\
\hline
\end{tabular}

\section{Discussion}

\subsection{Result Analysis for the Fuzzy MCDM Model}

As addressed in Section 4, the key project-specific analyzing criteria that need to be taken into account are determined, and four potential alternatives for the construction project are ranked through the proposed fall protection decision-making planning model. In this construction application problem, the top ranked criteria in order are: (1) Protection to user; (2) Equipment appropriateness; (3) Effort needed before installation; (4) End-user stability; (5) Labor productivity of executing tasks; (6) Simplicity; (7) Passivity; (8) Ergonomic comfort of workers; (9) Cost of protection system; (10) Aesthetics; (11) Efficiency of installation; (12) Cost of system installation and removal; (13) Flexibility; and (14) Maintenance and repair cost. The fall protection alternative ranking results illustrated in Table 10 show that the fall protection plan alternative $\mathrm{A} 3$ achieves the best performance as the closeness coefficient of $\mathrm{A} 3$ is the highest among all alternatives.

\subsection{Sensitivity Analysis of the Weight Changes of Criteria on the Fall Protection Decision-Making Results}

In order to test the robustness of the decision preference results, a sensitivity analysis of how the sub-criteria weight change affects the fall protection plan decision-making results is performed. As the relative importance between the criteria may change with the judgments of the selected respondents, criteria weights can be changed as well. This proposed model applied a simulation-based sensitivity analysis, and the output results are illustrated in Figures $6-8$, where the $x$-axis represents the weight changing condition number of each criterion and the $y$-axis represents the closeness coefficient of each alternative. It should be noted that the weight value of the main changing sub-criterion becomes larger as the weight changing condition number ( $x$-value) becomes larger in the simulation process. The weight of main changing criterion changes from $1 \%, 2 \%, 5 \%, 10 \%, 20 \%, 50 \%, 100 \%, 150 \%$, $200 \%, 250 \%, 300 \%, 350 \%$ and more times of the base weight, which corresponds to the weight changing condition number 1 to 12 , as shown in the $x$-axis. Specifically, the base weights of fourteen sub-criteria are the values obtained from the case study addressed above, and the corresponding changing condition number is seven (shown in yellow in Figures 6-8) in the simulation.

As shown in Figure 6, the sensitivity analysis of the sub-criteria C1, C2, C7, C12, C13, and $\mathrm{C} 14$ indicates that the selection of the optimal fall protection plan alternative will not change when the weights of these criteria change with the expert preference judgments in these cases. For example, in the $\mathrm{C} 1$ changing condition shown in Figure 6, as the main changing sub-criteria $\mathrm{C} 1$ becomes less important, the ranking of four alternatives does not change, indicating that the ranking results remain relatively stable compared with the initial ranking (shown in light yellow line in Figure 6). With the weight of $\mathrm{C} 1$ becoming larger, the performance score of A3 increases significantly, but the score of A1, A2 and A4 decreases rapidly. This leads to the fact that no matter how the $\mathrm{C} 1$ weight changes, $\mathrm{A} 3$ always achieves the best performance among the four potential alternatives. This shows that $\mathrm{A} 3$ is the optimal fall protection solution during $\mathrm{C} 1$ simulation runs. Similarly, when the weights of $\mathrm{C} 2, \mathrm{C} 7, \mathrm{C} 8, \mathrm{C} 12, \mathrm{C} 13$, and $\mathrm{C} 14$ are the main changing criteria, the ranking results keep relatively stable as well. Therefore, in these weight changing conditions, the final optimal solution is the same, which means A3 is always the optimal fall protection plan. 
C1 Criterion

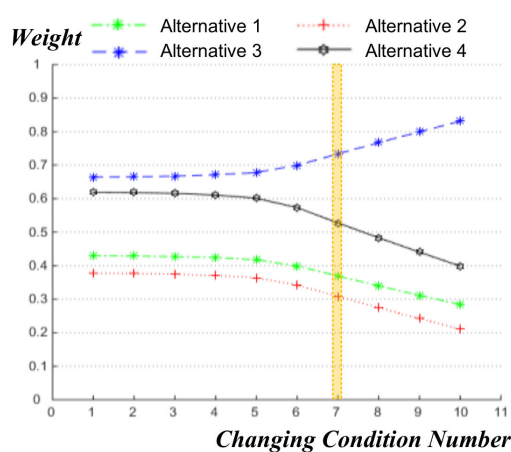

C12 Criterion

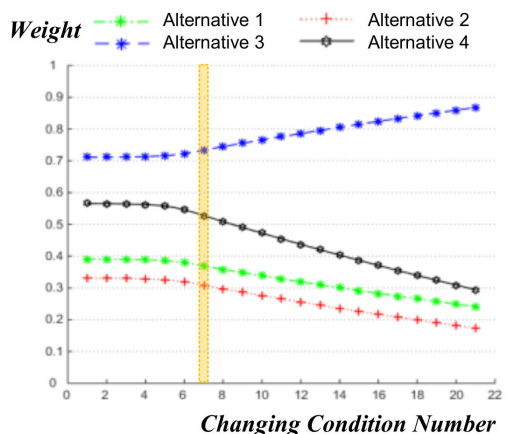

C2 Criterion

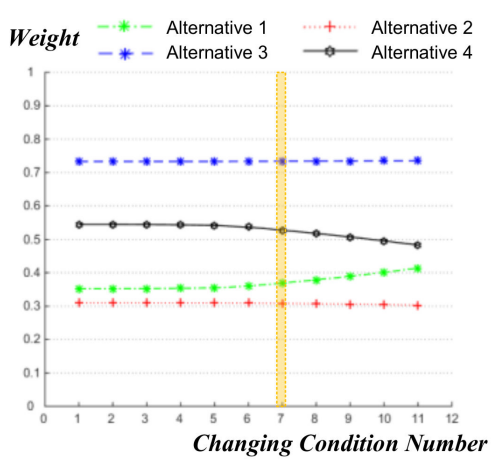

C13 Criterion

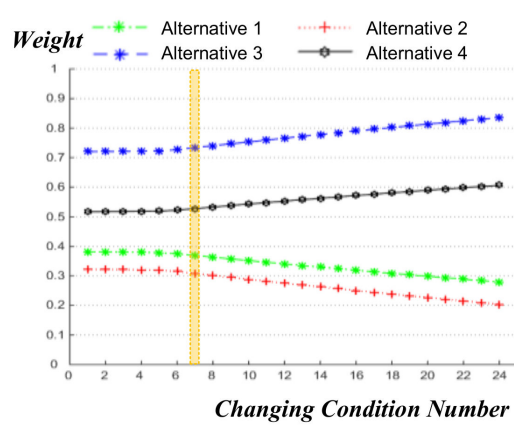

C7 Criterion

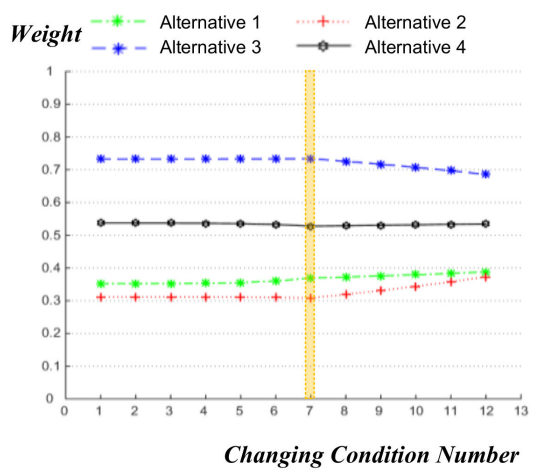

C14 Criterion

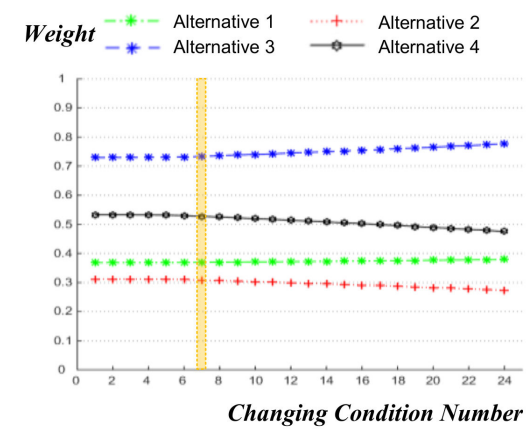

Figure 6. Sensitivity analysis results of sub-criteria C1, C2, C7, C12, C13 and C14.

\section{C3 Criterion}

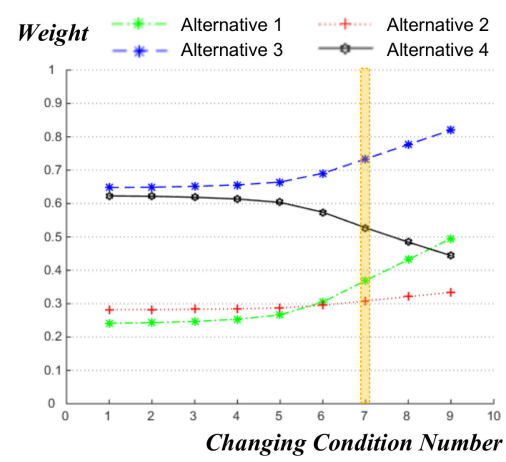

C9 Criterion

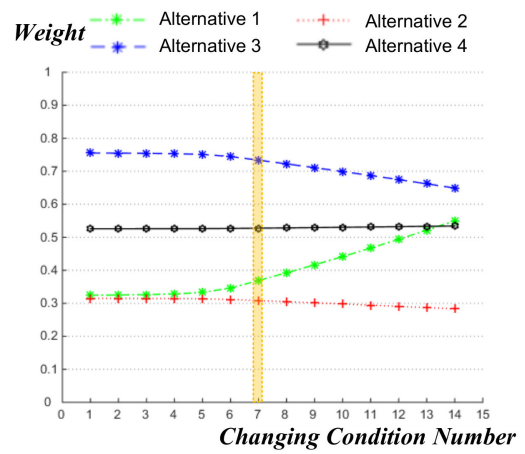

C4 Criterion

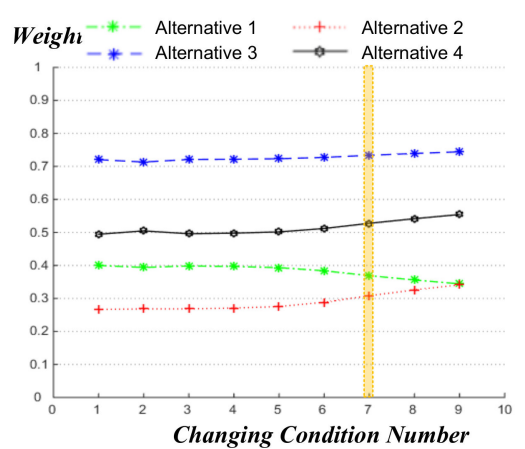

C11 Criterion

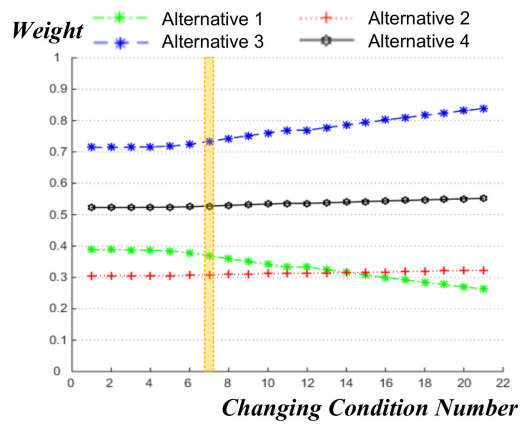

C6 Criterion

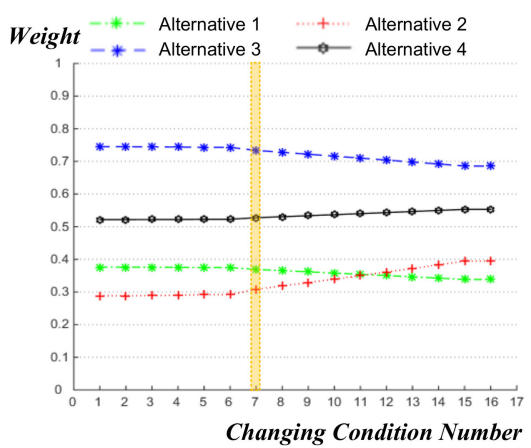

Figure 7. Sensitivity analysis results of sub-criteria C3, C4, C6, C9, and C11. 
C5 Criterion

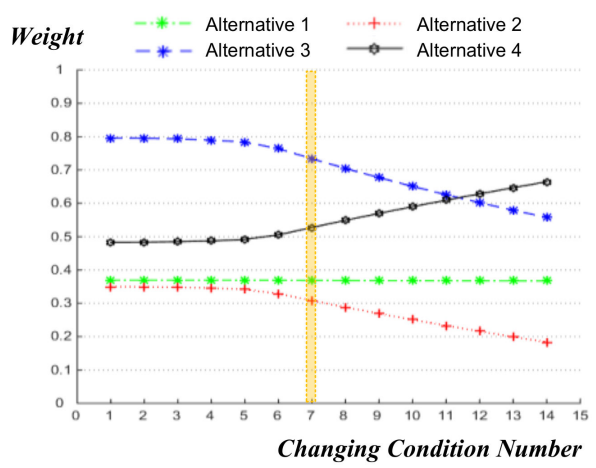

C8 Criterion

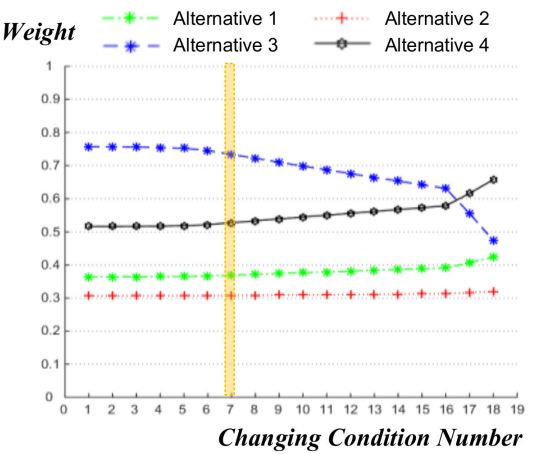

C10 Criterion

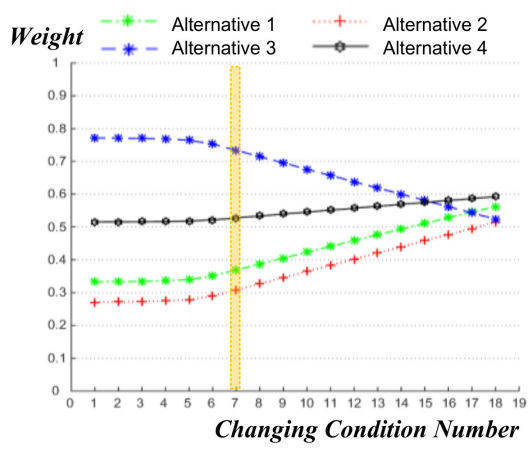

Figure 8. Sensitivity analysis results of sub-criteria C5, C8 and C10.

Figure 7 demonstrated the sensitivity results of the sub-criteria of C3, C4, C6, C9, and C11. In these cases, as the sub-criteria weights fluctuate, the optimal solution does not change, but the ranking of other alternatives may change. For example, in the C3 changing condition shown in Figure 7 , the overall ranking does not change significantly when the C3 weight decreases. Therefore, the optimal solution is still A3. However, when the $\mathrm{C} 3$ weight increases, the $\mathrm{CC}$ i value of $\mathrm{A} 2$ and $\mathrm{A} 3$ increases rapidly while that of $\mathrm{A} 1$ increases slowly. On the other hand, the performance of A4 becomes worse. While the weight of C3 increases more, the performance of A2 becomes better than A1 and A4. As a result, the overall ranking may change during the sensitivity simulation. However, in these changing conditions, A3 is always the optimal fall protection plan no matter how the criteria weights change.

From the other three sub-criteria changing conditions shown in Figure 8, it can be concluded that in C5, C8 and C10 changing conditions, the optimal solution may change. For example, in the C5 weight changing conditions as shown in Figure 9, the optimal solution may change with the criteria weights fluctuating. Specifically, the C5 weight changing scenario is illustrated in a $3 \mathrm{D}$ plot as shown in Figure 9, where the $x$-axis represents the weight changing condition number while the $y$-axis represents the $C_{i}$. The weight of $C 5$ changes from $1 \%, 2 \%, 5 \%, 10 \%, 20 \%, 50 \%, 100 \%, 150 \%, 200 \%, 250 \%, 300 \%, 350 \%, 400 \%$ and $450 \%$ of the base weight, which corresponds to condition $1,2,3,4,5,6,7,8,9,10,11,12,13$, and 14 , respectively. As the weight changes, the closeness coefficient of A3 decreases but the A4 score increases. Finally, the performance of A4 becomes better than that of A3. In this condition, A4 is the optimal fall protection plan. Similarly, in the C5, C8, C10 changing conditions, the final ranking results heavily depend on the sub-criteria weights, and the optimal solution should be analyzed and selected based on decision makers' preference on criteria weights and further analysis.

To summarize, from the above sensitivity analysis, A3 is the optimal fall protection plan alternative in most cases while A4 ranks the top in several conditions, and A1 and A2 are never the best fall protection plans. Therefore, planners and decision makers can select the optimal solution in A3 and A4 considering the actual construction conditions. The final result and alternative ranking of the proposed fuzzy MCDM model is effective and robust. 


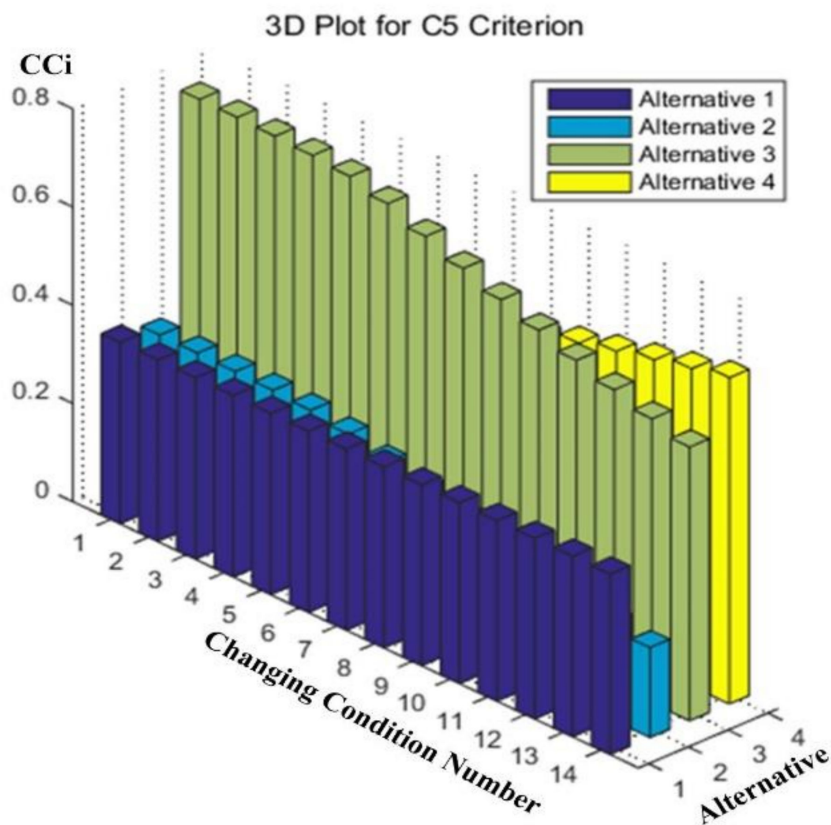

Figure 9. 3D histogram plot for performance changes in $\mathrm{C} 5$ main changing conditions.

\section{Conclusions}

This paper proposed a multi-criteria decision-making model for fall protection planning to assist construction safety management and accident prevention processes from the design phase to the evaluation phase. Since the majority of safety-related research in construction mainly focus on fall prevention techniques and injury analysis, this research focuses on the fall protection plan evaluation and selection to enhance productivity and cost goals during safety management in construction projects. In this paper, a fall protection MCDM system was developed with four identified main criteria and fourteen sub-criteria, and a fuzzy decision-making model was proposed for the plan evaluation and selection process. The model, main theories and the methodology are described in detail. The application process of the proposed model integrates various multicriteria decision-making approaches, including AHP, fuzzy sets, TOPSIS and simulationbased sensitivity analysis, and develops a framework to select the optimal fall protection plan for construction projects, which is novel and effective for safety optimization in construction projects.

The proposed model combines AHP, fuzzy sets and TOPSIS techniques to find the optimal fall protection system plan in construction projects. The priority weights of criteria in the safety evaluation system are effectively generated from AHP. Since there is a high level of uncertainty and ambiguity involved in the fall protection decisionmaking process, a fuzzy TOPSIS-based model was conjointly adopted for performance evaluation and alternative selection. This decision-making model utilizes construction planners and experts' opinions to assess fall protection plan alternatives according to performance scores of four main criteria and fourteen sub-criteria. Since the descriptions of human opinions may be complex and inaccurate, fuzzy set theory is employed to integrate quantitative assessment criteria in one single algorithm. Usage of fuzzy TOPSIS reflects the vagueness of the safety expert perceptions during the subjective judgment process. The simulation-based sensitivity analysis validates the stability and robustness of alternative ranking results. The results show that the AHP and fuzzy TOPSIS integrated multi-criteria model can enable a novel and effective procedure for decision-makers to evaluate multiple potential alternatives and select the optimal fall protection system plan along with setting productivity and cost goals without compromising the safety objective in construction management. 
Considering the limited number of sub-criteria in the assessment hierarchy, it is necessary to add more assessment criteria to improve the result accuracy of the multi-criteria decision-making method in future research. Moreover, to implement the decision-making approach into industry practices, the method can be further integrated into an automated BIM-based safety planning system. The proposed multi-criteria decision-making framework can be embedded into an automated system, where the preference information can be incorporated into the system to automatically generate the optimal safety plan. Therefore, based on the presented framework, construction managers can utilize the decision-making tool to select the optimal safety plan for various hazardous work areas on jobsites.

Author Contributions: Conceptualization, H.J. and P.M.G.; methodology, H.J.; software H.J.; validation, H.J. and P.M.G.; writing-original draft preparation, H.J.; writing-review and editing, H.J. and P.M.G.; supervision, P.M.G. All authors have read and agreed to the published version of the manuscript.

Funding: This research was supported by the China Postdoctoral Science Foundation (grant number 2020M680355) and Fundamental Research Funds for the Chinese Central Universities (grant number FRF-TP-20-020A1).

Institutional Review Board Statement: Not applicable.

Informed Consent Statement: Not applicable.

Data Availability Statement: The data presented in this study are available on request from the corresponding author.

Conflicts of Interest: The authors declare no conflict of interest.

\section{References}

1. U.S. Bureau of Labor Statistics (BLS). Census of Fatal Occupational Injuries: Number and Rate of Fatal Work Injuries by Industry Sector. Available online: https:/ / www.bls.gov/iif/oshwc/cfoi/cfch0014.pdf (accessed on 1 October 2017).

2. Cunningham, T.R.; Guerin, R.J.; Keller, B.M.; Flynn, M.A.; Salgado, C.; Hudson, D. Differences in safety training among smaller and larger construction firms with non-native workers: Evidence of overlapping vulnerabilities. Saf. Sci. 2018, 103, 62-69. [CrossRef] [PubMed]

3. U.S. Bureau of Labor Statistics (BLS). Census of Fatal Occupational Injuries. 2016. Available online: http://www.bls.gov/data/ \#injuries (accessed on 24 October 2016).

4. Guo, H.; Yu, Y.; Skitmore, M. Visualization technology-based construction safety management: A review. Autom. Constr. 2017, 73, 135-144. [CrossRef]

5. Akboğa, M.Ö.; Baradan, M.S. Investigating the characteristics of fatal construction injuries in İzmir, Turkey using descriptive statistics. J. Multidiscip. Eng. Sci. Technol. 2015, 2, 2475-2483.

6. Baradan, S.; Dikmen, S.U.; Akboga Kale, O. Impact of human development on safety consciousness in construction. Int. J. Occup. Saf. Ergon. 2019, 25, 40-50. [CrossRef]

7. Techera, U.; Hallowell, M.; Littlejohn, R. Worker Fatigue in Electrical-Transmission and Distribution-Line Construction. J. Constr. Eng. Manag. 2018, 145, 04018119. [CrossRef]

8. Mistikoglu, G.; Gerek, I.H.; Erdis, E.; Usmen, P.M.; Cakan, H.; Kazan, E.E. Decision tree analysis of construction fall accidents involving roofers. Expert Syst. Appl. 2015, 42, 2256-2263. [CrossRef]

9. Suruda, A.; Fosbroke, D.; Braddee, R. Fatal work-related falls from roofs. J. Saf. Res. 1995, 26, 1-8. [CrossRef]

10. Janicak, C.A. Fall-related deaths in the construction industry. J. Saf. Res. 1998, 29, 35-42. [CrossRef]

11. Chi, C.-F.; Chang, T.-C.; Ting, H.-I. Accident patterns and prevention measures for fatal occupational falls in the construction industry. Appl. Ergon. 2005, 36, 391-400. [CrossRef]

12. Dong, X.S.; Choi, S.D.; Borchardt, J.G.; Wang, X.; Largay, J.A. Fatal falls from roofs among US construction workers. J. Saf. Res. 2013, 44, 17-24. [CrossRef]

13. Jebelli, H.; Ahn, C.R.; Stentz, T.L. Fall risk analysis of construction workers using inertial measurement units: Validating the usefulness of the postural stability metrics in construction. Saf. Sci. 2016, 84, 161-170. [CrossRef]

14. U.S. Bureau of Labor Statistics (BLS). National Census of Fatal Occupational Injuries in 2015. Available online: https://www.bls. gov/news.release/archives/cfoi_12162016.pdf (accessed on 22 December 2019).

15. Umer, W.; Li, H.; Lu, W.; Szeto, G.P.Y.; Wong, A.Y. Development of a tool to monitor static balance of construction workers for proactive fall safety management. Autom. Constr. 2018, 94, 438-448. [CrossRef]

16. Cameron, I.; Gillan, G.; Roy Duff, A. Issues in the selection of fall prevention and arrest equipment. Eng. Constr. Archit. Manag. 2007, 14, 363-374. [CrossRef] 
17. Chan, A.P.; Wong, F.K.; Chan, D.W.; Yam, M.C.; Kwok, A.W.; Lam, E.W.; Cheung, E. Work at height fatalities in the repair, maintenance, alteration, and addition works. J. Constr. Eng. Manag. 2008, 134, 527-535. [CrossRef]

18. Yung, P. Institutional arrangements and construction safety in China: An empirical examination. Constr. Manag. Econ. 2009, 27, 439-450. [CrossRef]

19. Kim, H.-J.; Paik, S.-W. A study on the cause analysis of fall accidents at temporary construction sites. J. Korean Soc. Saf. 2010, $25,62-64$.

20. Hwang, B.-G.; Shan, M.; Phuah, S.L. Safety in green building construction projects in Singapore: Performance, critical issues, and improvement solutions. KSCE J. Civ. Eng. 2018, 22, 447-458. [CrossRef]

21. Earnest, G.S.; Branche, C.M. Knowledge Gaps and Emerging Issues for Fall Control in Construction. In Fall Prevention and Protection: Principles, Guidelines, and Practices; CRC Press: Boca Raton, FL, USA, 2016; pp. 469-490.

22. Gillen, M.; Faucett, J.A.; Beaumont, J.J.; McLoughlin, E. Injury severity associated with nonfatal construction falls. Am. J. Ind. Med. 1997, 32, 647-655. [CrossRef]

23. Duncan, C.W.; Bennett, R. Fall protection \& debris containment during construction. In Preparing for Construction in the 21st Century; American Society of Civil Engineers: Reston, VA, USA, 1991; pp. 97-102.

24. Weisgerber, F.; Wright, M. Elements of a fall safety through design program. Implement. Saf. Health Constr. Sites 1999, 8, 67-74.

25. Huang, X.; Hinze, J. Analysis of construction worker fall accidents. J. Constr. Eng. Manag. 2003, 129, 262-271. [CrossRef]

26. Singh, A. Innovative Fall Protection for Construction Workers on Low-Rise Roofs. In Construction Safety and Health Management; Prentice-Hall: Upper Saddle River, NJ, USA, 2000; pp. 87-114.

27. Zhang, S.; Sulankivi, K.; Kiviniemi, M.; Romo, I.; Eastman, C.M.; Teizer, J. BIM-based fall hazard identification and prevention in construction safety planning. Saf. Sci. 2015, 72, 31-45. [CrossRef]

28. American National Standards Institute. Minimum Requirements for a Comprehensive Managed Fall Protection Program; ANSI/ASSE Z359.2-2007; American Society of Safety Engineers: Reston, VA, USA, 2007.

29. Johnson, H.M.; Singh, A.; Young, R.H. Fall protection analysis for workers on residential roofs. J. Constr. Eng. Manag. 1998, 124, 418-428. [CrossRef]

30. Bentley, T.A.; Hide, S.; Tappin, D.; Moore, D.; Legg, S.; Ashby, L.; Parker, R. Investigating risk factors for slips, trips and falls in New Zealand residential construction using incident-centred and incident-independent methods. Ergonomics 2006, 49 , 62-77. [CrossRef] [PubMed]

31. Hallowell, M.R.; Gambatese, J.A. Activity-based safety risk quantification for concrete formwork construction. J. Constr. Eng. Manag. 2009, 135, 990-998. [CrossRef]

32. Dewlaney, K.S.; Hallowell, M.R.; Fortunato, B.R., III. Safety risk quantification for high performance sustainable building construction. J. Constr. Eng. Manag. 2011, 138, 964-971. [CrossRef]

33. Dharmapalan, V.; Gambatese, J.A.; Fradella, J.; Moghaddam Vahed, A. Quantification and assessment of safety risk in the design of multistory buildings. J. Constr. Eng. Manag. 2014, 141, 04014090. [CrossRef]

34. Saurin, T.A.; Formoso, C.T.; Guimarães, L.B. Safety and production: An integrated planning and control model. Constr. Manag. Econ. 2004, 22, 159-169. [CrossRef]

35. Hallowell, M.R.; Hinze, J.W.; Baud, K.C.; Wehle, A. Proactive construction safety control: Measuring, monitoring, and responding to safety leading indicators. J. Constr. Eng. Manag. 2013, 139, 04013010. [CrossRef]

36. Park, C.-S.; Kim, H.-J. A framework for construction safety management and visualization system. Autom. Constr. 2013, 33, 95-103. [CrossRef]

37. Li, X.; Yi, W.; Chi, H.-L.; Wang, X.; Chan, A.P. A critical review of virtual and augmented reality (VR/AR) applications in construction safety. Autom. Constr. 2018, 86, 150-162. [CrossRef]

38. Kiviniemi, M.; Sulankivi, K.; Kähkönen, K.; Mäkelä, T.; Merivirta, M.-L. BIM-based safety management and communication for building construction. VTT Tiedotteita 2011, 22, 1-123.

39. Navon, R.; Kolton, O. Model for automated monitoring of fall hazards in building construction. J. Constr. Eng. Manag. 2006, 132, 733-740. [CrossRef]

40. Esmaeil, B.; Hallowell, M.; Roucheray, M. Developing a framework for measuring the effectiveness of common fall prevention/protection practices. In Proceedings of the ICSDEC 2012: Developing the Frontier of Sustainable Design, Engineering, and Construction, Fort Worth, TX, USA, 7-9 November 2012; pp. 719-726.

41. Guo, B.H.; Goh, Y.M. Ontology for design of active fall protection systems. Autom. Constr. 2017, 82, 138-153. [CrossRef]

42. Hsiao, H.; Simeonov, P. Preventing falls from roofs: A critical review. Ergonomics 2001, 44, 537-561. [CrossRef]

43. Goh, Y.M.; Love, P.E. Adequacy of personal fall arrest energy absorbers in relation to heavy workers. Saf. Sci. 2010, 48, 747-754. [CrossRef]

44. Paine, D.M.; McCann, M. Evaluation of a decking fall protection system. Prof. Saf. 2004, 49, 40.

45. Ölçer, A.; Odabaşi, A. A new fuzzy multiple attributive group decision making methodology and its application to propulsion/manoeuvring system selection problem. Eur. J. Oper. Res. 2005, 166, 93-114. [CrossRef]

46. Tzeng, G.-H.; Huang, J.-J. Multiple Attribute Decision Making: Methods and Applications; Chapman and Hall: London, UK, 2011.

47. Saaty, T.L. Decision Making for Leaders: The Analytic Hierarchy Process for Decisions in a Complex World; RWS Publications: Pittsburgh, PA, USA, 1990.

48. Kendall, K.E.; Kendall, J.E. Systems Analysis and Design; Pearson Education Limited: New York, NY, USA, 2011. 
49. KarimiAzari, A.; Mousavi, N.; Mousavi, S.F.; Hosseini, S. Risk assessment model selection in construction industry. Expert Syst. Appl. 2011, 38, 9105-9111. [CrossRef]

50. Aminbakhsh, S.; Gunduz, M.; Sonmez, R. Safety risk assessment using analytic hierarchy process (AHP) during planning and budgeting of construction projects. J. Saf. Res. 2013, 46, 99-105. [CrossRef]

51. Raviv, G.; Shapira, A.; Fishbain, B. AHP-based analysis of the risk potential of safety incidents: Case study of cranes in the construction industry. Saf. Sci. 2017, 91, 298-309. [CrossRef]

52. Ilbahar, E.; Karaşan, A.; Cebi, S.; Kahraman, C. A novel approach to risk assessment for occupational health and safety using Pythagorean fuzzy AHP \& fuzzy inference system. Saf. Sci. 2018, 103, 124-136.

53. Shapira, A.; Simcha, M. AHP-based weighting of factors affecting safety on construction sites with tower cranes. J. Constr. Eng. Manag. 2009, 135, 307-318. [CrossRef]

54. Chan, A.H.; Kwok, W.; Duffy, V.G. Using AHP for determining priority in a safety management system. Ind. Manag. Data Syst. 2004, 104, 430-445. [CrossRef]

55. Liaudanskienè, R.; Ustinovičius, L.; Bogdanovičius, A. Evaluation of construction process safety solutions using the TOPSIS method. Inz. Ekon. 2015, 64, 32-40.

56. Bo, Y. Construction safety evaluation based on intuitionistic fuzzy TOPSIS. In Proceedings of the 2011 International Conference on Consumer Electronics, Communications and Networks (CECNet), Xianning, China, 5-20 January 2011.

57. Occupational Safety and Health Administration (OSHA). Workers' Compensation Costs of Falls in Construction; US Department of Labor: Washington, DC, USA, 2011.

58. Karakhan, A.; Gambatese, J.; Rajendran, S. Application of choosing by advantages decision-making system to select fall-protection measures. In Proceedings of the 24th Annual Conference of the International Group for Lean Construction, Boston, MA, USA, 20-22 July 2016.

59. Rajendran, S. Sustainable Construction Safety and Health Rating System. Ph.D. Thesis, University of Greenwich, London, UK, 2006.

60. Goh, Y.M.; Goh, W.M. Investigating the effectiveness of fall prevention plan and success factors for program-based safety interventions. Saf. Sci. 2016, 87, 186-194. [CrossRef]

61. Aneziris, O.; Papazoglou, I.A.; Baksteen, H.; Mud, M.; Ale, B.; Bellamy, L.J.; Hale, A.R.; Bloemhoff, A.; Post, J.; Oh, J. Quantified risk assessment for fall from height. Saf. Sci. 2008, 46, 198-220. [CrossRef]

62. Lan, A.; Arteau, J.; Sirard, C. Method for validating a multi-component safety system. Saf. Sci. 2004, 42, 493-517. [CrossRef]

63. Baszczyński, K.; Zrobek, Z. Dynamic performance of horizontal flexible anchor lines during fall arrest-A numerical method of simulation. Int. J. Occup. Saf. Ergon. 2000, 6, 521-534. [CrossRef]

64. Irizarry, J.; Simonsen, K.L.; Abraham, D.M. Effect of safety and environmental variables on task durations in steel erection. J. Constr. Eng. Manag. 2005, 131, 1310-1319. [CrossRef]

65. Mitropoulos, P.; Namboodiri, M. New method for measuring the safety risk of construction activities: Task demand assessment. J. Constr. Eng. Manag. 2010, 137, 30-38. [CrossRef]

66. Martin, J. Selection and use of fall protection and rescue equipment for work on towers. In Proceedings of the ESMO-93: Sixth International Conference on Transmission and Distribution Construction and Live-Line Maintenance, Las Vegas, NV, USA, 12-17 September 1993; Institute of Electrical and Electronics Engineers (IEEE): New York, NY, USA, 1993; pp. 117-126.

67. Saaty, T.L. How to make a decision: The analytic hierarchy process. Eur. J. Oper. Res. 1990, 48, 9-26. [CrossRef]

68. Zadeh, L.A. Fuzzy sets. Inf. Control. 1965, 8, 338-353. [CrossRef]

69. Govindan, K.; Khodaverdi, R.; Jafarian, A. A fuzzy multi criteria approach for measuring sustainability performance of a supplier based on triple bottom line approach. J. Clean Prod. 2013, 47, 345-354. [CrossRef]

70. Yen, J.; Langari, R. Fuzzy Logic: Intelligence, Control, and Information; Prentice Hall: Upper Saddle River, NJ, USA, 1999 ; Volume 1.

71. Kolar, Z.; Chen, H.; Luo, X. Transfer learning and deep convolutional neural networks for safety guardrail detection in $2 \mathrm{D}$ images. Autom. Constr. 2018, 89, 58-70. [CrossRef] 